Published in final edited form as:

Messenger (Los Angel). 2016 June 1; 5(1-2): 37-55. doi:10.1166/msr.2016.1054.

\title{
Acidic $\mathrm{Ca}^{2+}$ stores in neurodegeneration
}

\author{
Emyr Lloyd-Evans \\ School of Biosciences, Sir Martin Evans Building, Cardiff University, Museum Avenue, Cardiff, \\ CF10 3AX
}

\section{Abstract}

Lysosomes have emerged in the last decade as an immensely important intracellular site of $\mathrm{Ca}^{2+}$ storage and signalling. More recently there has been an increase in the number of new ion channels found to be functional on lysosomes and the potential roles that these signalling pathways might play in fundamental cellular processes are being uncovered. Defects in lysosomal function have been shown to result in changes in lysosomal $\mathrm{Ca}^{2+}$ homeostasis and ultimately can result in cell death. Several neurodegenerative diseases, from rare lysosomal storage diseases through to more common diseases of ageing, have recently been identified as having alterations in lysosomal $\mathrm{Ca}^{2+}$ homeostasis that may play an important role in neuronal excitotoxicity and ultimately cell death. This review will critically summarise these recent findings.

\section{Introduction}

In recent years, acidic endo-lysosomal $\mathrm{Ca}^{2+}$ stores have emerged as a major component of intracellular $\mathrm{Ca}^{2+}$ signalling in mammalian cells(Patel \& Cai, 2015). $\mathrm{Ca}^{2+}$ is one of the most important signalling molecules inside and outside of cells and is an important component of the triggering of fertilization, cell growth and motility and ultimately cell death(Berridge, Lipp et al., 2000). Within cells $\mathrm{Ca}^{2+}$ levels are tightly regulated with $\mathrm{nM}$ to low $\mu \mathrm{M}$ levels in the cytosol and high $\mu \mathrm{M}$ to low $\mathrm{mM}$ levels within some organelles such as the endoplasmic reticulum and acidic stores such as late endosomes and lysosomes(Lloyd-Evans \& Platt, 2011). Changes in cytosolic $\mathrm{Ca}^{2+}$ levels, via $\mathrm{Ca}^{2+}$ release from intracellular organelles or $\mathrm{Ca}^{2+}$ entry from the extracellular fluid, triggers cellular changes(Berridge et al., 2000). $\mathrm{Ca}^{2+}$ channels present on the plasma membranes or intracellular organelles act in response to extracellular stimuli (primary messengers) or intracellular second messengers such as nicotinic acid adenine dinucleotide phosphate (NAADP) to either trigger $\mathrm{Ca}^{2+}$ entry into the cell or $\mathrm{Ca}^{2+}$ exit from organelles(Galione \& Churchill, 2002). In order to restore cytosolic $\mathrm{Ca}^{2+}$ levels back to their normally low levels a variety of pumps and transporters exist that transport $\mathrm{Ca}^{2+}$ out of the cell and into intracellular organelles(Brini \& Carafoli, 2011, Mekahli, Bultynck et al., 2011). Failure to maintain cytosolic $\mathrm{Ca}^{2+}$ levels can lead to continuously elevated $\mathrm{Ca}^{2+}$ that can trigger excitotoxicity and cell death(Berridge et al., 2000, Mekahli et al., 2011). One intracellular organelle that appears to regulate global changes in $\mathrm{Ca}^{2+}$ signalling and which may act to modulate excitotoxic changes in cytosolic $\mathrm{Ca}^{2+}$ is the lysosome(Lloyd-Evans \& Platt, 2011, Lloyd-Evans, Waller-Evans et al., 2010).

Lloyd-EvansE@cardiff.ac.uk, Tel: +44(0)2920874304. 
This review aims to highlight the role of the lysosome as a $\mathrm{Ca}^{2+}$ store that is involved in the pathogenesis of multiple neurodegenerative diseases.

\section{The need for $\mathrm{Ca}^{2+}$ in the endo-lysosomal system}

The endo-lysosomal system is an essential series of distinct compartments found in all nucleated cells(Luzio, Pryor et al., 2007). Endocytosis is the process by which material from the extracellular fluid enters the cells, either by binding to receptors or by fluid phase endocytosis, via budding from the plasma membrane. From here, vesicles fuse with the early endosomes and deposited cargo is transported from early endosomes to the late endosome whereas most receptors are recycled back out of the cell via the endocytic recycling compartment. Cargo in the late endosome is usually delivered to lysosomes, the terminal point of the endocytic system, for degradation(Luzio, Parkinson et al., 2009). Lysosomes have an acidic lumen, ranging from $\mathrm{pH}$ 4-5 dependent on cell type(Lloyd-Evans, Morgan et al., 2008), and are comprising numerous highly glycosylated transmembrane proteins that form a protective lumenal glycocalyx to prevent self digestion by the lysosomes own high content of acidic hyrolases (Schulze, Kolter et al., 2009). Lysosomes are the main recycling centre of the cell with the products of this degradation of macromolecules being redistributed to endoplasmic reticulum (ER) or Golgi by vesicular transport or pumped into the cytosol via the action of lysosomal membrane transporters(Saftig \& Klumperman, 2009). Lysosomes are also essential in the degradation of defective organelles, particularly mitochondria, and mis-folded proteins, all of which enter the lysosomal system through either autophagic vacuole fusion with late endosomes or chaperone mediated autophagy(Platt, Boland et al., 2012).

All of these processes of transport along the endocytic system, membrane recycling and autophagic vacuole fusion are $\mathrm{Ca}^{2+}$ dependent processes(Lloyd-Evans et al., 2010, Piper \& Luzio, 2004). An early breakthrough in our understanding of how $\mathrm{Ca}^{2+}$ regulates endocytic processes was the finding that localised $\mathrm{Ca}^{2+}$ release is required for the fusion of lysosomes with late endosomes. Using a fast $\mathrm{Ca}^{2+}$ chelator, BAPTA, versus the slower acting EGTA, it was found that fusion between purified late endosomes and lysosomes could be inhibited. Furthermore, the amount of $\mathrm{Ca}^{2+}$ required to induce fusion between these organelles was in the range of $0.1-10 \mu \mathrm{M}$. Taken together, this would suggest a rapid localised $\mathrm{Ca}^{2+}$ release most likely from a substantial intraorganellar $\mathrm{Ca}^{2+}$ store(Pryor, Mullock et al., 2000). Further understanding of the role of $\mathrm{Ca}^{2+}$ in regulating endocytosis came from the discovery that the $\mathrm{Ca}^{2+}$ dependent phospholipid binding protein Annexin A2, whch mediates cargo delivery between membranes, is required for normal transport of vesicular cargo between early endosomes and late endosomes(Lloyd-Evans et al., 2008, Mayran, Parton et al., 2003). Disruption in endosomal $\mathrm{Ca}^{2+}$ handling, the mechanisms of which are discussed in more detail below, can lead to severe disruption in endocytic and cellular function(Lloyd-Evans \& Platt, 2011, Lloyd-Evans et al., 2010). Enhanced $\mathrm{Ca}^{2+}$ release from lysosomes in response to the second messenger NAADP has been shown to lead to defective endocytosis and recycling of lipids out of late endosomes and lysosomes resulting in their accumulation within enlarged lysosomes(Ruas, Rietdorf et al., 2010). Disruption of $\mathrm{Ca}^{2+}$ signalling is also known to lead to defects in autophagic vacuole-lysosome fusion(Gordon, Holen et al., 1993, La Rovere, Roest et al., 2016), another endocytic process which requires localised $\mathrm{Ca}^{2+}$ 
release from lysosomes(Medina, Di Paola et al., 2015), defects in this signalling result in accumulation of autophagosomes and defective mitochondria within cells(Medina \& Ballabio, 2015). Furthermore, defects in endo-lysosomal $\mathrm{Ca}^{2+}$ release are coupled to changes in pigmentation (Lin-Moshier, Keebler et al., 2014), potentially as a result of altered lysosomal exocytosis. All of these disruptions in the endocytic system are known to occur in neurodegenerative lysosomal storage diseases and more common diseases of ageing(Lloyd-Evans \& Haslett, 2016b), and are discussed in more detail below.

\section{Endo-lysosomes are a major intracellular $\mathrm{Ca}^{2+}$ store}

Although the largest $\mathrm{Ca}^{2+}$ store within the cell is the endoplasmic reticulum (ranging from 0.1-1mM (Bygrave \& Benedetti, 1996)), it has become apparent in recent years that the endocytic system, especially the so called acidic stores, namely the late endosomes and lysosomes, contain substantial levels of $\mathrm{Ca}^{2+}$ (Christensen, Myers et al., 2002, Lloyd-Evans et al., 2008). It should however be noted that although the intra-organellar $\mathrm{Ca}^{2+}$ content within lysosomes is high (see below), volumetrically lysosomes are predicted as being only $2-3 \%$ of the total cellular volume(Thoene, 1992). As such their impact on changing whole cell cytosolic $\mathrm{Ca}^{2+}$ levels should be minimal in comparison to ER (>10\% of the cellular volume(Voeltz, Rolls et al., 2002)) $\mathrm{Ca}^{2+}$ release or extracellular $\mathrm{Ca}^{2+}$ influx. However, recent studies have indicated that lysosomal $\mathrm{Ca}^{2+}$ release can trigger substantial $\mathrm{Ca}^{2+}$ release from the ER which in turn has a global effect on elevating cellular $\mathrm{Ca}^{2+}$ levels(Kilpatrick, Eden et al., 2013, Morgan, Davis et al., 2013). The observation of high intra-lumenal lysosomal $\mathrm{Ca}^{2+}$ levels explain the origin of the localised elevations in $\mathrm{Ca}^{2+}$ that are required for endo-lysosomal fusion and endocytic vesicle transport discussed above(Pryor et al., 2000). Rather than changes in global $\mathrm{Ca}^{2+}$ eliciting endocytic transport and recycling, it would appear that this is regulated instead by $\mathrm{Ca}^{2+}$ release from endo-lysosomal stores. This was confirmed by studies using dextran conjugated $\mathrm{Ca}^{2+}$ chelators endocytosed into lysosomes that induced lysosomal lipid storage and endocytic trafficking abnormalities, indicating that lumenal lysosomal $\mathrm{Ca}^{2+}$ is indeed critical for endocytosis(Lloyd-Evans et al., 2008). Whilst extracellular $\mathrm{Ca}^{2+}$ levels are high (can range from $1.2-1.8 \mathrm{mM}$ in plasma, interstitial fluid and cerebrospinal fluid(Jones \& Keep, 1988)), the intra-lumenal $\mathrm{Ca}^{2+}$ content of early endosomes has been measured as being in the range of $5-30 \mu \mathrm{M}$ (Gerasimenko, Tepikin et al., 1998). The reason for this discrepancy, which is substantial when one considers the volume of extracellular fluid that continuously enters early endosomes, is the initiation of acidification of the endocytic system at the early endosome level by the action of the $\mathrm{H}^{+}$pumping vacuolar ATPase (v-ATPase)(Gerasimenko et al., 1998, Lelouvier \& Puertollano, 2011). This process results in loss of $\mathrm{Ca}^{2+}$ from the early endosomal lumen to the cytosol, suggested to be mediated by the transient receptor potential mucolipin (TRPML3) ion channel(Lelouvier \& Puertollano, 2011). Furthermore, it has been shown that endocytosis contributes very little to the overall $\mathrm{Ca}^{2+}$ content of the acidic stores (Christensen et al., 2002). Using dextran conjugated $\mathrm{Ca}^{2+}$ probes we and others have shown that it is possible to specifically load the lysosome with these probes through a pulse/chase experiment. By adjusting the $\mathrm{Kd}$ of the $\mathrm{Ca}^{2+}$ probe for the $\mathrm{pH}$ of the lysosome, and ensuring that a low affinity $\mathrm{Ca}^{2+}$ probe is used, it is then possible to measure the intra luminal free $\mathrm{Ca}^{2+}$ content of this highly acidic organelle. We have found that although there 
is some slight differences when comparing cell types, on the whole lysosomal $\mathrm{Ca}^{2+}$ appears to be in the range of 500-600 $\mu \mathrm{M}$ (Christensen et al., 2002, Lloyd-Evans et al., 2008), indicating that this is the second largest $\mathrm{Ca}^{2+}$ store within the cell. How lysosomal $\mathrm{Ca}^{2+}$ levels are maintained is discussed in more detail below, and is summarised in Fig. 1, but we are aware that maintenance of the $\mathrm{pH}$ gradient is essential as disruption of the v-ATPases leads to expulsion of $\mathrm{Ca}^{2+}$ from lysosomes in a similar manner to that which occurs from the ER following inhibition of the ER $\mathrm{Ca}^{2+}$ ATPase (SERCA) with thapsigargin(Christensen et al., 2002, Kilpatrick, Magalhaes et al., 2016a).

\section{Maintenance of endo-lysosomal $\mathrm{Ca}^{2+}$ levels; pumps, transporters and channels}

\section{Lysosomal $\mathrm{Ca}^{2+}$ entry mechanisms}

The mechanisms governing $\mathrm{Ca}^{2+}$ entry into lysosomes remain largely unknown. Evidence for the presence of an ATPase on lysosomal membranes has emerged from studies into neutrophils and platelets. Platelet dense core granules, organelles very similar to lysosomes, have been shown to contain SERCA3a and it's inhibition by TBHQ resulted in a reduction in lysosomal $\mathrm{Ca}^{2+}$ content(Lopez, Jardin et al., 2008). Furthermore, studies in neutrophils have shown the presence of a high affinity ATP dependent lysosomal $\mathrm{Ca}^{2+}$ uptake pump that was depdendent on $\mathrm{Mg}^{2+}$ (Klemper, 1985). Studies in purified lysosomes however have shown the presence of ATP independent $\mathrm{Ca}^{2+}$ entry that can be inhibited by heavy metals including $\mathrm{Zn}^{2+}$ and $\mathrm{Mg}^{2+}$ but not by monovalent ions, is also inhibited by L-cystine and is less efficient when the cytosol is acidified(Lemons \& Thoene, 1991). This may provide support for the presence of $\mathrm{Ca}^{2+} / \mathrm{H}^{+}$exchangers on lysosomal membranes similar to the CAX family which have recently been identified on the lysosomes of non-placental mammals (Melchionda, Pittman et al., 2016) or the solute transporter SLC24A5, a $\mathrm{K}^{+}$ dependent $\mathrm{Na}^{+} / \mathrm{Ca}^{2+}$ transporter, has been shown to be important in pigmentation in zebrafish and humans and resides on the surface of melanosomes, a lysosome related organelle(Lamason, Mohideen et al., 2005). Ultimately, the identification of pumps and transporters that could fill the lysosome with $\mathrm{Ca}^{2+}$ remains a major fundamental area of research for the lysosomal $\mathrm{Ca}^{2+}$ field with the majority of evidence pointing towards some form of transport mechanism reliant on $\mathrm{pH}$ (Morgan, Platt et al., 2011). However, a recent study has suggested that $\mathrm{Ca}^{2+}$ uptake into lysosomes is not dependent on acidification but instead the ER is utilised, via $\mathrm{Ca}^{2+}$ release from InsP3 receptors, to fill the lysosome with $\mathrm{Ca}^{2+}$ (Garrity, Wang et al., 2016). This study is supported by others indicating that lysosomes selectively sequester $\mathrm{Ca}^{2+}$ released from the ER (as opposed to $\mathrm{Ca}^{2+}$ entering the cell via store operated pathways) via contact points between these organelles(Lopez Sanjurjo, Tovey et al., 2014, Lopez-Sanjurjo, Tovey et al., 2013). However, these studies also indicate that blocking lysosomal acidification with bafilomycin can perturb the ability of lysosomes to sequester $\mathrm{Ca}^{2+}$ released from the ER(Lopez Sanjurjo et al., 2014). All of these studies are in keeping with the findings that alteration in lysosomal $\mathrm{pH}$ in familial Alzheimer disease (FAD) cells results in reduced, but not completely diminished, levels of lysosomal $\mathrm{Ca}^{2+}$ (Coen, Flannagan et al., 2012, Lee, McBrayer et al., 2015). This is described in more detail below but the defect in lysosomal $\mathrm{Ca}^{2+}$ in these cells is believed to be activation of TRPML1, a late endosomal/lysosomal ion channel, triggered by abnormal lysoosmal $\mathrm{pH}$ 
incurring a $\mathrm{Ca}^{2+}$ leak via TRPML1 out of lysosomes(Lee et al., 2015). This and other studies would therefore suggest that lysosomal $\mathrm{pH}$ can maintain endogenous lysosomal $\mathrm{Ca}^{2+}$ levels by controlling lysosomal $\mathrm{Ca}^{2+}$ uptake from the ER and also triggering lysosomal $\mathrm{Ca}^{2+}$ release (Christensen et al., 2002, Lopez Sanjurjo et al., 2014, Morgan \& Galione, 2007). It is also evident that $\mathrm{Ca}^{2+}$ release from lysosomes can also induce $\mathrm{Ca}^{2+}$ release from the ER(Kilpatrick et al., 2013), this is mediated by defined channels described below.

\section{Lysosomal $\mathrm{Ca}^{2+}$ release mechanisms}

The same is also true for lysosomal $\mathrm{Ca}^{2+}$ release, where a plethora of ion channels are now believed to be involved. The two pore channel 2 (TPC2) and the TRPML1 channel are the two best characterised of these ion channels (reviewed in (Patel \& Cai, 2015)) but recent evidence has also emerged suggesting that the purinergic ATP activated cation channel P2X4 and the voltage gated $\mathrm{Ca}^{2+}$ channel CACNA1a are also present on lysosomes(Cao, Zhong et al., 2015, Huang, Zou et al., 2014, Tian, Gala et al., 2015). For the purpose of this review we will focus on TPC2 and TRPML1 as these two lysosomal ion channels are the ones most associated with neurodegenerative diseases. TPC2 was originally identified as the channel that transports $\mathrm{Ca}^{2+}$ out of lysosomes in response to the most potent intracellular $\mathrm{Ca}^{2+}$ releasing second messenger NAADP(Brailoiu, Churamani et al., 2009, Calcraft, Ruas et al., 2009), which had previously been shown to target lysosomes(Churchill, Okada et al., 2002). Based on single channel recordings, TPC2 is known to respond reversibly to NAADP under acidic luminal conditions ( $\mathrm{pH} 4.8$ ) and responds to lower concentrations of NAADP when luminal lysosomal $\mathrm{Ca}^{2+}$ concentration is higher, suggesting that luminal $\mathrm{Ca}^{2+}$ and $\mathrm{pH}$ both regulate TPC activity(Pitt, Funnell et al., 2010). The channel has been shown to be capable of transporting $\mathrm{Na}^{+}$(Wang, Zhang et al., 2012) but appears to primarily transport $\mathrm{Ca}^{2+}$ (Pitt, Lam et al., 2014) and evidence that TPC2 does not respond to NAADP has been refuted (Ruas, Davis et al., 2015).

In addition to TPC2, the late endosomal/lysosomal system has another well characterised $\mathrm{Ca}^{2+}$ permeant channel known as TRPML1. TRPML1 is, at present, the only TRP family member of ion channels exclusively present in the lysosome (TRPM2, a plasma membrane channel, has also been identified on lysosomes(Lange, Yamamoto et al., 2009)) and loss of function is associated with the human lysosomal storage disease mucolipidosis type IV (MLIV) described in detail below. Initially, TRPML1 was believed to be a candidate NAADP responsive channel (Zhang, Jin et al., 2009), but this was shown not to be the case as overexpression of TRPML1 does not enhance NAADP mediated $\mathrm{Ca}^{2+}$ release (whereas TPC2 does (Yamaguchi, Jha et al., 2011)). Subsequently, the endogenous ligand for TRPML1 was identified as being phosphatidylinositol 3,5-bisphosphate $\left(\mathrm{PI}(3,5) \mathrm{P}_{2}\right)($ Dong, Shen et al., 2010), which is also capable of modulating TPC2 activity(Jha, Ahuja et al., 2014, Wang et al., 2012). TRPML1 appears to operate in both late endosomes and lysosomes (Piper \& Luzio, 2004, Wong, Li et al., 2012) and is permeant to multiple ions including, $\mathrm{Ca}^{2+}, \mathrm{Fe}^{2+}, \mathrm{Na}^{+}, \mathrm{K}^{+}$and $\mathrm{Zn}^{2+}$ (Cuajungco, Basilio et al., 2014, Dong, Cheng et al., 2008, LaPlante, Falardeau et al., 2002). Functionally, $\mathrm{Ca}^{2+}$ signalling mediated by TRPML1 has been linked to the biogenesis of lysosomes and the clearance of autophagic vacuoles via activation of the transcription factor EB (TFEB) (Medina et al., 2015, Medina, Fraldi et al., 2011). 


\section{Abnormal lysosomal $\mathrm{Ca}^{2+}$ signalling as a contributing factor to neurodegeneration and cellular dysfunction in the lysosomal storage diseases}

Defects in lysosomal $\mathrm{Ca}^{2+}$ maintenance or signalling have been associated with human diseases, mainly with the lysosomal storage disorders (Lloyd-Evans et al., 2010), a group of predominantly childhood neurodegenerative diseases (Cox \& Cachon-Gonzalez, 2012). Lysosomal storage diseases (LSDs), whilst being individually rare, are collectively the most common form of childhood neurodegenerative disease occurring at a combined frequency of 1:5,000 live births and comprise a family of $>60$ diseases (Cox \& Cachon-Gonzalez, 2012). The majority are caused by defects in lysosomal enzymes, but an increasing cohort of $\sim 20$ are caused by genetic mutations in genes encoding for lysosomal transmembrane proteins (Lloyd-Evans \& Platt, 2010). For almost all of these diseases the exact mechanisms that lead to neuronal cell death remain largely unknown and treatment options for most of the diseases are limited to palliative care(Platt \& Jeyakumar, 2008). Work by us and others has led to the emergence of evidence connecting several of these disorders with defects in intracellular $\mathrm{Ca}^{2+}$ handling, that in some cases results in excitotoxicity, and has been directly shown to result in neuronal cell loss (Lloyd-Evans et al., 2008, Lloyd-Evans, Pelled et al., 2003a, Pelled, Lloyd-Evans et al., 2003, Pereira, Gazarini et al., 2010, Tessitore, del et al., 2004). The evidence for involvement of $\mathrm{Ca}^{2+}$ in the pathophysiology of these diseases is summarised in Table 1 and some of this work has been reviewed previously(Lloyd-Evans et al., 2010). In some cases the main defect has been alterations in $\mathrm{Ca}^{2+}$ handling in intracellular stores other than the lysosome (Korkotian, Schwarz et al., 1999), these diseases are not discussed in detail here but information can be found elsewhere (Vitner, Platt et al., 2010). Furthermore, new lysosomal diseases with defects in lysosomal $\mathrm{Ca} 2+$ homeostasis are being identified. One example being CLN3 disease, a member of the neuronal ceroid lipofuscinoses, caused by mutations in the $C L N 3$ gene encoding the predominantly lysosomal CLN3 protein of unknown function(Chandrachud, Walker et al., 2015). Cells and tissues from this disease accumulate autofluorescent lipofuscin in lysosomes and have substantial abnormalities in the production and clearance of autophagic vacuoles(Cao, Espinola et al., 2006). A recent study has demonstrated the presence of elevated lysosomal $\mathrm{Ca}^{2+}$ in a cerebellar cell line from the CLN3 exon $7 / 81 \mathrm{~kb}$ deletion mouse model(Chandrachud et al., 2015), the first report of such an increase in any disease. Further work is required to determine the cause of this defect and the role it may play in the pathogenesis of CLN3 disease.

\section{Niemann-Pick disease type $\mathrm{C}$, a disease of reduced lysosomal $\mathrm{Ca}^{2+}$ and defective lipid endocytosis}

The first reported case of a defect in lysosomal $\mathrm{Ca}^{2+}$ in a human disease was that of Niemann-Pick type C (NPC) disease (Lloyd-Evans et al., 2008). NPC is an LSD that manifests primarily with loss of cerebellar Purkinje neurons that results in ataxia, however, neuronal dysfunction is widespread and hallmarks of Alzheimer's have also been reported (Lloyd-Evans \& Platt, 2010). Patients usually succumb to the disease in their second decade of life but adult onset forms of the disease as well as milder disease causing mutations have 
all been reported(Millat, Marcais et al., 2001, Vanier \& Millat, 2003). The disease is caused by mutation in the $N P C 1$ gene that encodes a 13 transmembrane domain protein of the limiting membrane of the lysosome, also called NPC1 (Lloyd-Evans \& Platt, 2010). The exact function of NPC1 remains to be identified but it is believed to be involved in lipid transport, especially cholesterol and potentially sphingolipids and fatty acids (Ioannou, 2005, Lloyd-Evans \& Platt, 2010). NPC1 belongs to the eukaryotic family of resistance nodulation division (RND) permease multi-substrate pumps that are capable of transporting antibiotics, heavy metals, detergents, dyes and lipids, all of which have been reported to accumulate in NPC disease lysosomes (Davies, Chen et al., 2000, Kaufmann \& Krise, 2008, Tseng, Gratwick et al., 1999). NPC lysosomes accumulate cholesterol, simple sphingolipids including sphingosine, glycosphingolipids, sphingomyelin and lyso-(bis)phospatidic acid (LBPA)(Lloyd-Evans et al., 2008, Lloyd-Evans \& Platt, 2010). In 2008 we determined that multiple cell lines from NPC disease (NPC1 null Chinese hamster ovary cells, NPC1 null mouse astrocytes, NPC patient fibroblasts) as well as cells treated with the NPC1 protein inhibitor U18666a (Lu, Liang et al., 2015) all had reduced levels of lysosomal $\mathrm{Ca}^{2+}$ (measured both directly with intra-lumenal dextran conjugated $\mathrm{Ca}^{2+}$ probes as well as indirect pharmacological release of $\mathrm{Ca}^{2+}$ from lysosomes to the cytosol for measurement with a membrane permeant fluorescent $\mathrm{Ca}^{2+}$ dye) as well as reduced lysosomal $\mathrm{Ca}^{2+}$ release in response to membrane permeant NAADP-AM (Lloyd-Evans et al., 2008). The impact of this defect in lysosomal $\mathrm{Ca}^{2+}$ homeostasis in NPC disease is an inhibition of fusion and endocytic transport between the component parts of the endo-lysosomal system, leading to the large accumulation of lipids within NPC cells and tissues(Lloyd-Evans et al., 2008, Visentin, De Nuccio et al., 2013). Indeed the importance of the $\mathrm{Ca}^{2+}$ defect to disease pathology was highlighted by the use of curcumin as a potential therapy(Borbon, Hillman et al., 2012, Efthymiou, Steiner et al., 2015, Lloyd-Evans et al., 2008). Curcumin acts to elevate cytosolic $\mathrm{Ca}^{2+}$ levels by weak inhibition of SERCA and uncovering of the activity of the $\mathrm{ER} \mathrm{Ca}^{2+}$ leak channels (Bilmen, Khan et al., 2001). Curcumin led to a significant improvement in function and lifespan of the NPC mouse model (Lloyd-Evans et al., 2008), with a significant rescue of Purkinje cell degeneration in the cerebellum(Smith, Wallom et al., 2009). However any benefit may well have been ameliorated by the action of curcumin against the cytochrome p450 enzymes (Wang, Sun et al., 2015), the activity of which have been shown to be considerably reduced in NPC disease (Nicoli, Al Eisa et al., 2016). The potential benefit of curcumin (in a lipidated vector) has also been questioned (Borbon et al., 2012) as has the cellular benefit (Yu, Swaroop et al., 2014), the low concentrations of curcumin used in this cell based study $(2-5 \mu \mathrm{M})$ are highly unlikely to induce significant elevation in cytosolic $\mathrm{Ca}^{2+}$ in order to rescue endo-lysosomal function in NPC disease cells. Indeed, it is this requirement for higher concentrations of curcumin (10-30 $\mu \mathrm{M}$ (Lloyd-Evans et al., 2008)), higher than those found in the plasma and CSF (0.2-1.8 $\mu \mathrm{M}$ (Mishra \& Palanivelu, 2008)), to induce $\mathrm{Ca}^{2+}$ elevation within cells that has led to the speculation that curcumin cannot mediate benefit in this way in NPC disease (Borbon et al., 2012). However, it should be noted that it's effects are not due to its well-known antioxidant properties (Smith et al., 2009) and low doses of curcumin given to Tg2576 mutant APP overexpressing Alzheimer mice over a period of time were capable of crossing the blood brain barrier and accumulating in the CNS where they stained amyloid deposits(Yang, Lim et al., 2005). As such, it is possible that curcumin eventually reaches a high enough concentration within 
cells to weakly inhibit SERCA and induce changes in $\mathrm{Ca}^{2+}$, further work is required in this area.

The defect in lysosomal $\mathrm{Ca}^{2+}$ in NPC disease was shown to be triggered by the accumulation of sphingosine (Lloyd-Evans et al., 2008), which has recently been suggested to activate TPC 1 and induce emptying of the lysosomal $\mathrm{Ca}^{2+}$ store (Hoglinger, Haberkant et al., 2015). This is an interesting hypothesis and one that requires testing by inhibiting the $\mathrm{Ca}^{2+}$ release with the NAADP receptor inhibitor Ned19 (Naylor, Arredouani et al., 2009), which should therefore theoretically rescue NPC disease phenotypes. It is also interesting to note that the accumulation of sphingosine in NPC disease cells $(\sim 1 \mu \mathrm{M}$ (Lloyd-Evans \& Platt, 2010)) is not sufficient to alter lysosomal pH (which is normal in NPC disease (Bach, Chen et al., 1999, Lloyd-Evans et al., 2008)), or induce lysosomal membrane rupture, which can happen at higher concentrations of sphingosine (Kagedal, Zhao et al., 2001, LloydEvans \& Platt, 2011). As it has been reported that activation of $\mathrm{Ca}^{2+}$ release from lysosomes with NAADP induces a change in lysosomal pH (Morgan \& Galione, 2007), it would appear that this enhanced $\mathrm{Ca}^{2+}$ release is not occurring constitutively, even though lysosomal $\mathrm{Ca}^{2+}$ levels remain constitutively lower (Lloyd-Evans et al., 2008). Furthermore, it has been shown that it requires $\sim 10 \mu \mathrm{M}$ sphingosine or more to induce $\mathrm{Ca}^{2+}$ release from lysosomes (Lloyd-Evans \& Platt, 2011), a concentration $~ 10$ fold greater than is actually found in NPC disease storage lysosomes (Lloyd-Evans \& Platt, 2010). Another possibility is that sphingosine accumulation is inhibiting the mechanism of $\mathrm{Ca}^{2+}$ entry into NPC disease lysosomes, as it is a known inhibitor of $\mathrm{Ca}^{2+}$ ATPases(Colina, Cervino et al., 2002, Pandol, Schoeffield-Payne et al., 1994), the activity of which have been found on purified lysosomes(Ezaki, Himeno et al., 1992). Clearly more work is required to establish the exact mechanism by which lysosomal $\mathrm{Ca}^{2+}$ levels are reduced in NPC disease.

One study has suggested that lysosomal $\mathrm{Ca}^{2+}$ levels are in fact not reduced in NPC disease (Shen, Wang et al., 2012). This study is in contention with multiple reports from various research labs (Coen et al., 2012, Hoglinger et al., 2015, Lee, Lee et al., 2010a, Lee, Lee et al., 2014, Lloyd-Evans et al., 2008, Speak, Te Vruchte et al., 2014, Visentin et al., 2013, Xu, Liu et al., 2012). Several of these labs have used either the same NPC patient fibroblast cell line (Visentin et al., 2013, Xu et al., 2012) that was used in the original study(Lloyd-Evans et al., 2008), or a U18666a induced cellular model of NPC disease(Coen et al., 2012, LloydEvans et al., 2008), and all of whom have reported a reduction in lysosomal $\mathrm{Ca}^{2+}$ in NPC disease and often by various methods in multiple cells including Purkinje neurons(Lee et al., 2010a). One possibility for the discrepancy in the results is indeed the tools and methods used in the studies. In our initial paper we presented data that NPC disease B lymphoblasts had lower lysosomal $\mathrm{Ca}^{2+}$ than controls using the lysosomal cathepsin $\mathrm{C}$ substrate GPN alone to burst lysosomes(Lloyd-Evans et al., 2008). The data from the other NPC cell lines used in the paper (CHO, human patient fibroblast and RAW macrophages treated with the NPC1 inhibitor U18666a) was the same but we had to use a slightly different method to fully realise the difference in lysosomal $\mathrm{Ca}^{2+}$ that we had also measured with an in situ dextran conjugated $\mathrm{Ca}^{2+}$ probe(Lloyd-Evans et al., 2008). In these other cell lines we first clamped the other intracellular stores with either thapsigargin (to release $\mathrm{ER} \mathrm{Ca}^{2+}$ ) or ionomycin (to release all intracellular $\mathrm{Ca}^{2+}$ stores apart from lysosomes) prior to releasing lysosomal $\mathrm{Ca}^{2+}$ with GPN(Lloyd-Evans et al., 2008). We did not require any clamping of the 
other intracellular $\mathrm{Ca}^{2+}$ stores in the $\mathrm{B}$ lymphoblasts as the mechanisms governing potentiation of lysosomal $\mathrm{Ca}^{2+}$ release by the ER appear to be different in these immortalised B cells (Waller-Evans and Lloyd-Evans unpublished, (Dellis, Arbabian et al., 2009)). Shown in Fig. 2 is the difference we observe in lysosomal $\mathrm{Ca}^{2+}$ content in fibroblasts when we compare cells that have had the intracellular stores clamped prior to either NAADP-AM or GPN addition versus those that have not. As can be seen, there is a substantially smaller lysosomal $\mathrm{Ca}^{2+}$ release in the cells which have not been clamped, which correlates more closely with the intra-lumenal measurements and the low volumetric content of lysosomes within cells. It is therefore clear that clamping of intracellular stores is crucial in order to conduct accurate indirect measurements of the content of the lysosomal $\mathrm{Ca}^{2+}$ store, it is unclear whether this is the case in Shen et al.

\section{Is there a role for TRPML1, the lysosomal $\mathrm{Ca}^{2+}$ channel defective in mucolipidosis type IV, in the pathogenesis of Niemann-Pick disease type $C$ ?}

Inhibition of TRPML1 by lysosomal sphingomyelin has been suggested as a possible mechanism for altering lysosomal $\mathrm{Ca}^{2+}$ homeostasis in NPC disease(Shen et al., 2012). That sphingomyelin is unlikely to affect TRPML1 is supported by the findings that inhibition of sphingolipid biosynthesis with myriocin, which reduces sphingosine levels first, rescues the lysosomal $\mathrm{Ca}^{2+}$ defect prior to any correction in sphingomyelin levels(Lloyd-Evans et al., 2008). Furthermore, the authors indicate that overexpression of TRPML1 or its activation with the agonist MLSA1 is capable of correcting the defects in endocytic trafficking and cholesterol accumulation observed in different NPC cell lines(Shen et al., 2012). It is therefore interesting to point out that some of their lysosomal $\mathrm{Ca}^{2+}$ measurements in NPC cells were made using a construct that overexpresses a $\mathrm{Ca}^{2+}$ measuring GCaMP attached to TRPML1(Shen et al., 2012), which in itself may not distinguish between $\mathrm{Ca}^{2+}$ release from lysosomes or more global $\mathrm{Ca}^{2+}$ signalling events as highlighted by(Kilpatrick, Yates et al., 2016b). If overexpression of TRPML1 rescues NPC lysosomal phenotypes then theoretically this may correct the defect in lysosomal $\mathrm{Ca}^{2+}$ so that there is ultimately no difference to measure. It is also interesting to note that in a separate study by the same group there was no effect of MLSA1 on lysosomal cholesterol in NPC1 null Chinese hamster ovary cells, NPC1 null macrophages or U18666a treated control macrophages(Wang, Gao et al., 2015). This discrepancy is yet to be fully explained. Finally, should TRPML1 be rendered dysfunctional in NPC disease then one would expect some degree of phenotypic overlap between NPC disease cells and cells from the lysosomal disease mucolipidosis type IV (MLIV) where genetic mutations in the MCOLN1 gene render the gene product, TRPML1, inactive, dysfunctional or absent(Bach, 2001).

\section{Does pathogenesis of mucolipidosis type IV mirror Niemann-Pick disease type C?}

We have previously summarised the main differences in phenotypes at the cellular level between NPC and MLIV (Lloyd-Evans \& Platt, 2011) we now summarise the main differences in patient symptoms (table 2). Although the two diseases are clearly genetically distinct, one would expect some significant degree of overlap in phenotypes if TRPML1 was rendered dysfunctional in both diseases. For example, autofluorescence is well recorded in MLIV cells and tissues but reports of lipofuscin accumulation in NPC disease do not exist in the literature apart from one study (Shen et al., 2012) where apparent autofluorescent 
material in NPC cells is co-localised against lysotracker red, a probe well known for its ability to rapidly photoconvert into a green fluorescent molecule (Freundt, Czapiga et al., 2007). At the patient level, a major phenotype in MLIV is elevated blood gastrin levels, iron deficiency in some patients and the presence of achlorhydria from defects in Parietal cell function which affects the acidity of gastric secretions(Schiffmann, Dwyer et al., 1998). There have been no achlorhydria in NPC patients. Ultimately, based on the weight of evidence from a number of different research groups, it would appear that lysosomal $\mathrm{Ca}^{2+}$ is reduced in NPC disease. Indeed, this reduced lysosomal $\mathrm{Ca}^{2+}$ level defect has been used as a phenotypic output in a high throughput drug screen in NPC patient fibroblasts by the NIH (Xu et al., 2012) and elevation of lysosomal $\mathrm{Ca}^{2+}$ has been shown to be beneficial in a number of independent studies (Visentin et al., 2013, Xu et al., 2012).

\section{What is the role of loss of TRPML1 function in the pathogenesis of mucolipidosis type IV?}

Loss of function of TRPML1 in MLIV disease results in a clinical phenotype that is embodied by initial rapid neurological decline during early infancy followed by stabilisation for multiple decades(Bach, 2001). The disease is also characterised by ophthalmological defects, abnormal blood gastrin levels and achlorhydria(Schiffmann et al., 1998). At the cellular level, there is an accumulation of lipids (gangliosides and phospholipids(Bach, Zeigler et al., 1980, Bargal \& Bach, 1988, Bargal \& Bach, 1989)), glycosaminoglycans (Bach, Ziegler et al., 1977) and $\mathrm{Fe}^{2+}$ (Dong et al., 2008) within lysosomes that themselves have altered pH and accelerated lipid recycling(Bach et al., 1999, Chen, Bach et al., 1998). Mutations in the MCOLN1 gene, that encodes TRPML1, are the cause of MLIV(Bargal, Avidan et al., 2000). As mentioned earlier, TRPML1 is a late endosomal and lysosomal ion channel permeant to multiple ions including, $\mathrm{Ca}^{2+}, \mathrm{H}^{+}, \mathrm{Na}^{+}, \mathrm{K}^{+}$and $\mathrm{Zn}^{2+}$ (Cuajungco et al., 2014, Dong et al., 2008, LaPlante et al., 2002). Interestingly, recent work has indicated that TRPML1 may be involved in triggering $\mathrm{Ca}^{2+}$ release from the ER (Kilpatrick et al., 2016b) suggesting an impact on global $\mathrm{Ca}^{2+}$ signalling as well as an ability to regulate autophagy through activation of TFEB via the $\mathrm{Ca}^{2+}$ dependent calcineurin(Medina et al., 2015). It has also been reported that TRPML1 is regulated by pH(Cantiello, Montalbetti et al., 2005, Raychowdhury, Gonzalez-Perrett et al., 2004), a finding which was unexpectedly supported in familial Alzheimer's disease where loss of function mutations in PSEN1 encoding presenilin 1 (PSEN1) leads to defects in lysosomal pH that activate TRPML1 and empty the lysosomal $\mathrm{Ca}^{2+}$ store (discussed in more detail below) (Lee et al., 2015). The vast majority of work on TRPML1 has been done using constitutively active mutant forms of TRPML1, how exactly these mutant proteins recapitulate the function of wild-type TRPML1 remains largely unknown(Waller-Evans \& Lloyd-Evans, 2015).

\section{Common neurodegenerative diseases with defects in lysosomal $\mathrm{Ca}^{2+}$}

\section{Parkinson's disease}

Parkinson's disease (PD), one of the most common neurodegenerative diseases, is a progressive idiopathic neurodegenerative disease of ageing that affects $>1 \%$ of the population aged over 65 and $>4 \%$ of over 85's (de Rijk, Launer et al., 2000). As well as age, both genetic (PARK gene family) and environmental factors (e.g. traumatic brain injuries, exposure to pesticides, exposure to metals such as $\mathrm{Mn}^{2+}$ ) have been identified as 
contributors to the prevalence of this disease(Lai, Marion et al., 2002). PD is the most common movement disorder(Tong, Yamaguchi et al., 2010), the motor defects synonymous with PD are caused by loss of the dopaminergic neurons in the substantia nigra and dopaminergic terminals in the striatum(Dauer \& Przedborski, 2003). Loss of neurons is associated with the presence of intracellular inclusions known as Lewy bodies with low molecular weight oligomers of a-synuclein thought to be the primary cause of the neurotoxicity(Planchard, Exley et al., 2014). Evidence that $\mathrm{Ca}^{2+}$ signalling is critical in PD for survival of the dopaminergic neurons in the substantia nigra pars compacta comes from the observation of reduced susceptibility to degeneration in neurons expressing the $\mathrm{Ca}^{2+}$ binding and buffering protein calbindin-D28K(Yamada, McGeer et al., 1990). Although several studies exist on the role of changes in $\mathrm{Ca}^{2+}$ signalling in inducing neuronal excitotoxicity in $\mathrm{PD}(\mathrm{Schulz}, 2007)$, changes in lysosomal $\mathrm{Ca}^{2+}$ signalling have only been explored in recent years. Neuronal cell death in PD is associated to the release of ATP from the cytosol to the extracellular space. This elevation, comparing 1-10nM ATP in the extracellular space to $10 \mathrm{mM}$ in the cytosol, results in both an increase in a-synuclein and the activation of ATP responsive P2X channels on neighbouring neurons and the influx of $\mathrm{Ca}^{2+}$ into the cell. Interestingly, this elevation in $\mathrm{Ca}^{2+}$ mediated by $\mathrm{P} 2 \mathrm{X}$ channels was shown to induce lysosomal alkalinisation and an increase in autophagic vacuoles(Gan, Moussaud et al., 2015). Further evidence for a potential role of lysosomal $\mathrm{Ca}^{2+}$ in PD emerged from a pharmacologically induced model where cathepsin B and L activity, known to be important in lysosomal a-synuclein degradation(McGlinchey \& Lee, 2015), was inhibited by Z-PheAla-diazomethylketone. Neurons treated with this inhibitor had expanded lysosomes, elevated lysosomal $\mathrm{Ca}^{2+}$ and elevated lysosomal $\mathrm{Ca}^{2+}$ release in response to NAADPAM(Dickinson, Churchill et al., 2010). Similar phenotypes (described below) have now been identified in various PD models.

A subset of the $P A R K$ genes are associated with lysosomes and the endo-lysosomal system, these include; the lysosomal p-type ATPase 13A2 (PARK13), the leucine-rich repeat kinase LRRK2 (PARK8) and the lysosomal enzyme glucocerebrosidase (GBAI). The GBA1 gene has recently emerged as a major risk factor for PD with an estimated $10 \%$ of sporadic cases of PD thought to be caused by heterozygous mutations in this gene(Sidransky, Nalls et al., 2009). Whilst the exact mechanisms linking reduced activity of glucocerebrosidase (GlcCerase) to loss of substantia nigra dopaminergic neurons remain unknown there has been compelling evidence linking mis-folded GlcCerase to ER dysfunction. The accumulation of mutant GlcCerase in the ER leads to elevated stress (Westbroek, Gustafson et al., 2011) and abnormally elevated ER $\mathrm{Ca}^{2+}$ release has been reported in PD patient fibroblasts carrying the N370S mutation in GBA1(Kilpatrick et al., 2016a). Indeed, abnormal $\mathrm{ER} \mathrm{Ca}^{2+}$ release via the ryanodine receptor is a hallmark of Gaucher disease (Korkotian et al., 1999, Pelled, Trajkovic-Bodennec et al., 2005), the most common lysosomal disease caused by loss of function mutations in $G B A 1$, and is observed in patient post-mortem brain as well as in mouse neurons where GlcCerase is pharmacologically inhibited by conduritol $\beta$-epoxide (CBE)(Korkotian et al., 1999, Pelled et al., 2005). In PD caused by heterozygous mutations in $G B A 1$ the cause of the $\mathrm{ER} \mathrm{Ca}^{2+}$ defect is likely different to Gaucher disease as it is unlikely that there is any storage of the GlcCerase substrate glucosylceramide, as residual enzyme activity must drop to below $15 \%$ of normal 
for lysosomal glucosylceramide storage to occur as is observed in Gaucher disease(Schueler, Kolter et al., 2004). Further evidence that the ER $\mathrm{Ca}^{2+}$ defect in PD does not occur as a result of lipid storage is that this phenotype is observed in PD patient fibroblasts, which are known to not accumulate glucosylceramide(Westbroek, Nguyen et al., 2016). It therefore appears that there is a significant difference between PD caused by heterozygosity in GBA1 and Gaucher disease as although both diseases have abnormal ER $\mathrm{Ca}^{2+}$ homeostasis the underlying cause is different as it is the lipid storage that induces this phenotype in Gaucher disease(Lloyd-Evans et al., 2003a, Lloyd-Evans, Pelled et al., 2003b). It is interesting however to note that a defect in lysosomal $\mathrm{Ca}^{2+}$ levels was observed in PD patient fibroblasts carrying the N370S mutation, with lower $\mathrm{Ca}^{2+}$ levels being released into the cytosol of the cells following osmotic lysis of lysosomes with GPN(Kilpatrick et al., 2016a). This phenotype appears to resemble NPC disease where the accumulation of Lewy bodies in NPC patient post-mortem brain has been reported (Chiba, Komori et al., 2014), suggesting a potential connection. It is also interesting to note that the activity of GlcCerase is reduced in NPC cells as a result of mis-localisation of the enzyme to late endosomes(Salvioli, Scarpa et al., 2004), alongside the accumulation of cholesterol in both NPC disease and Gaucher disease(Lloyd-Evans \& Platt, 2010, Ron \& Horowitz, 2008), there are some compelling simialrities that warrant further investigation in future. Interestingly, no $\mathrm{ER} \mathrm{Ca}^{2+}$ defect was observed in fibroblasts where GlcCerase was inhibited by CBE (only in the PD patient fibroblasts heterozygous for $G B A 1$ mutations, (Kilpatrick et al., 2016a)), which contrasts with earlier studies on Gaucher disease (Korkotian et al., 1999). However it should be noted that although GlcCerase activity was reported as being negligible in these CBE treated cells, the concentration of CBE used $(10 \mu \mathrm{M})$ was low and based on other studies would potentially inhibit GlcCerase to levels no lower than at least $25 \%$ of control (Dermentzaki, Dimitriou et al., 2013), which, based on 15\% of enzyme activity being enough to prevent lysosomal storage(Schueler et al., 2004), would not lead to a phenotype resembling Gaucher disease (which would not happen in fibroblasts either as they do not store glucosylceramide) but would in fact be more similar to the level of residual enzyme activity in PD. The very fact that this result with the GlcCerase inhibitor CBE does not resemble what is seen in PD patient cells where GlcCerase is potentially mis-folded again indicates that the mechanisms underlying the $\mathrm{Ca}^{2+}$ defects in both diseases are quite different, even if they do ultimately resemble one another.

Autosomal dominant mutations in PARK8 encoding LRRK2 is one of the most common genetic causes of PD and result in a rare late-onset familial PD that is indistinguishable from sporadic forms of PD (Gomez-Suaga, Luzon-Toro et al., 2012, Tong et al., 2010). Large genome wide association studies (GWAS) have also shown the presence of more common genetic variants in LRRK2 associated with the risk of non-familial PD(Simon-Sanchez, Schulte et al., 2009). Whilst the exact function of the LRRK2 protein is unknown it has been shown to have both Ras-like GTPase and MAPKKK-like kinase domains (Marin, 2006) and is a protein that is found on the ER as well as endo-lysosomes(Biskup, Moore et al., 2006). A role for LRRK2 in endo-lysosomal function first emerged from the findings that mice null for LRRK2 present with elevated levels of a-synuclein, elevated levels of autophagy, as indicated by an increase in the autophagosomal marker LC3-II, and an increase in lipofuscin, indicative of lysosomal dysfunction (Tong et al., 2010). These findings have been 
further supported from research into invertebrate models of PD, the Drosophila homologue of LRRK2 (Lrrk) localises exclusively to late endosomes and lysosomes where it interacts with and negatively regulates the function of Rab7, a GTPase that regulates endocytic transport. Wild-type LrrK appears to restrict the perinuclear localisation of lysosomes, whilst a Drosophila mutant lrrk that resembles the pathogenic human PD causing $L R R K 2^{G 2019 S}$ mutation promotes perinuclear lysosomal clustering with the presence of occasionally expanded late endosomes (Dodson, Zhang et al., 2012). Interestingly, expression in mouse primary astrocytes of LRRK2 harbouring not only the common $L R R K 2$ mutation G2019S but also the expression of other mutations such as R1441C or Y1699C all led to enlarged lysosomes, a phenotype that could be reversed using a LRRK2 kinase inhibitor(Henry, Aghamohammadzadeh et al., 2015). Of interest to the potential role of LRRK2 in modulating endosome and lysosome function in the pathophysiology of PD are the findings from genetic studies of PD patient cohorts indicating increased risk of PD caused by overlap of common variants in $L R R K 2$ with variants at another PD risk associated locus, PARK16 (MacLeod, Rhinn et al., 2013, Pihlstrom, Rengmark et al., 2015). Although several genes are contained within this locus, one in particular, namely $R A B 7$-like variant 1 $(R A B 7 L 1)$, provides a further connection to dysfunctional endo-lysosomes in $\mathrm{PD}$ and a genetic link between LRRK2 mutations and altered function of endocytic Rab7 GTPases. Furthermore, inhibition of Rab7 in PD patient fibroblasts carrying the common G2019S mutation in LRRK2 led to a correction in the perinuclear clustering of lysosomes (Hockey, Kilpatrick et al., 2015), providing further evidence of the interplay between LRRK2 and Rab7 in regulating endo-lysosomal function in both healthy cells (negative regulation) and in PD (gain of function). Interestingly, the beneficial effect of inhibiting Rab7 function on lysosomal clustering in PD patient cells could be replicated by genetic silencing of the expression of the lysosomal $\mathrm{Ca}^{2+}$ channel TPC2 (but not the endosomal channel TPC1) or inhibition of the TPC2 channel with Ned-19. This benefit was attributed to the presence of a defect in lysosomal $\mathrm{Ca}^{2+}$ in the PD patient cells with greater NAADP mediated $\mathrm{Ca}^{2+}$ release from lysosomes observed in the PD cells compared to controls(Hockey et al., 2015). Overexpression of TPC2, and elevated lysosomal $\mathrm{Ca}^{2+}$ release, has been connected with defects in endocytosis and autophagic vacuole clearance with an associated defect in recruitment of Rab7 to autophagosomes(Lu, Hao et al., 2013). Furthermore, TPC2 has been shown to coimmunoprecipitate with LRRK2 (Gomez-Suaga et al., 2012) raising the possibility that mutant LRRK2 may lead to enhanced activity of TPC2 and greater lysosomal $\mathrm{Ca}^{2+}$ release via abnormal TPC2 phosphorylation resulting in lysosomal accumulation and defects in autophagic vacuole clearance via altered Rab7 recruitment. This raises the possibility that treating downstream abnormal lysosomal $\mathrm{Ca}^{2+}$ signalling may be a potential therapeutic strategy for certain forms of PD, especially as inhibition of TPC 2 with Ned-19 has been shown to rescue the defects in lysosomal clustering (Hockey et al., 2015) and the accumulation of autophagic vacuoles (Gomez-Suaga et al., 2012) associated with abnormal LRRK2 function.

Indeed, the possibility that modulating lysosomal $\mathrm{Ca}^{2+}$ is a therapeutic strategy that could be looked at more broadly for PD is supported by the recent study indicating that ambroxol, a drug that is used as an expectorant and is a known chaperone for GlcCerase(Ambrosi, Ghezzi et al., 2015), can induce $\mathrm{Ca}^{2+}$ release from lysosomes via alkalinisation(Fois, Hobi et 
al., 2015). However, it should be noted that the levels of LAMP1 and 2, LIMP2 and GlcCerase have all been reported to be lower in multiple regions of the PD brain, as well as the substantia nigra, (Chu, Dodiya et al., 2009, Murphy, Gysbers et al., 2014, Rothaug, Zunke et al., 2014). Although, whether or not these cases of PD were associated with mutations in LRRK2 is unclear but would suggest that further work is required and that the lysosomal $\mathrm{Ca}^{2+}$ phenotypes discussed above are not only disparate but also may not be a universal feature of PD.

\section{Alzheimer's disease}

Alzheimer's disease (AD) is a complex, multifactorial and polygenic disease of aging that constitutes a major healthcare burden worldwide. $\mathrm{AD}$ is a disease of the aging brain where the normal processing, breakdown and recycling of proteins such as the amyloid precursor protein in cells of the brain is deficient. How exactly these defects lead to dysfunction and loss of neurons remains to be fully elucidated but there is an emerging role of lysosomes. For a comprehensive background on the role of lysosomes in AD see(Lloyd-Evans \& Haslett, 2016a). As with PD, lysosomal $\mathrm{Ca}^{2+}$ defects and an expanded lysosomal system have also been reported in $\mathrm{AD}$ (Wilson, Murphy et al., 2004). In particular, FAD caused by mutations in the PSEN1 gene encoding Presenilin 1 (PSEN1) a component of the $\gamma$ secretase complex that cleaves the amyloid precursor protein(Coen et al., 2012). Changes in lysosomal pH have been reported multiple times in PSEN1 null and mutant cells (Avrahami, Farfara et al., 2013, Coffey, Beckel et al., 2014, Lee et al., 2015, Lee, Yu et al., 2010b), suggesting a posibile cause of the altered lysosomal $\mathrm{Ca}^{2+}$ levels. It has been reported that the lysosomal $\mathrm{pH}$ defects in PSEN1 null cells are caused by abnormal glycosylation, in the absence of PSEN1, of the V0a1 subunit of the v-ATPase (Lee et al., 2015, Lee et al., 2010b). This in turn results in reduced v-ATPase activity and an alkalinisation of lysosomes which was proposed to cause defects in lysosomal protein processing and reduced clearance of autophagic vacuoles(Lee et al., 2015, Lee et al., 2010b). It has also been suggested that there is no defect in lysosomal pH in PSEN1 null cells and that the accumulation of autophagic vacuoles and lysosomal processing defects are the result of abnormal fusion between these compartments caused by the reduced lysosomal $\mathrm{Ca}^{2+}$ (Coen et al., 2012). Interestingly, these findings suggest a possible mechanistic similarity to NPC disease, discussed above, especially as the NPC1 inhibitor U18666a (Lu et al., 2015) induces the same lysosomal $\mathrm{Ca}^{2+}$ dysfunction in all studies(Coen et al., 2012, Lee et al., 2015, Lloyd-Evans et al., 2008).

Furthermore, NPC patients present with some hallmarks of Alzheimer like pathology(Saito, Suzuki et al., 2002). However, it appears that the mechanism governing lysosomal $\mathrm{Ca}^{2+}$ dysfunction in PSEN1 null cells and NPC disease cells is quite different. The change in lysosomal pH in PSEN1, which is not observed in NPC disease(Bach et al., 1999, LloydEvans et al., 2008), triggers a number of changes in the mechanisms that govern lysosomal $\mathrm{Ca}^{2+}$ homeostasis. First, NAADP has been shown to be incapable of dissociating from purified TPC2 when luminal lysosomal $\mathrm{pH}$ is less acidic. This results in an inability of NAADP to trigger further $\mathrm{Ca}^{2+}$ release via TPC2 (Pitt et al., 2010). We have shown that NAADP-AM signalling is completely inhibited in PSEN1 null cells, providing supportive evidence for a change in lysosomal $\mathrm{pH}$ (Lee et al., 2015). This change in NAADP signalling was not caused by any alteration in TPC 2 protein levels but could have been the result of overall reduced lysosomal $\mathrm{Ca}^{2+}$ levels in the PSEN1 cells. However, NAADP-AM induced 
no release from PSEN1 in comparison to U18666a treated cells, an inhibitor of lysosomal NPC1 which induced a similar reduction in lysosomal $\mathrm{Ca}^{2+}$ to that seen in PSEN1, where there was $\sim 80 \%$ less $\mathrm{Ca}^{2+}$ release compared to control(Lee et al., 2015). This suggested to us that TPC 2 had been rendered inactive by a change in lysosomal $\mathrm{pH}$. As mentioned above, TRPML1 has been suggested to be activated following a change in lysosomal $\mathrm{pH}$, potentially operating in late endosomes or homotypic organelles (Piper \& Luzio, 2004, Raychowdhury et al., 2004). Based on the change in lysosomal pH in PSEN1 cells we tested this theory and found that the synthetic agonist of TRPML1, MLSA1, was able to induce significantly more $\mathrm{Ca}^{2+}$ release from PSEN1 lysosomes(Lee et al., 2015). We concluded that hyperactive TRPML1 was the cause of the alteration in lysosomal $\mathrm{Ca}^{2+}$ as inhibition of PIKfyve, the enzyme that creates PI $(3,5) \mathrm{P}_{2}$ the endogenous ligand of TRPML1, was able to normalise PSEN1 lysosomal $\mathrm{Ca}^{2+}$ (Lee et al., 2015). It is also interesting to note that the amyloid precursor protein (APP) itself binds to PIKfyve and regulates the levels of $\mathrm{PI}(3,5) \mathrm{P}_{2}$ (Currinn, Guscott et al., 2016)providing the possibility that APP itself regulates TRPML1 activity.

Interestingly, TRPML1 activity has also been shown to be altered in other forms of dementia. Amyloid- $\beta$ accumulates by an unknown mechanism within neurons of brains infected with HIV and have been shown to accumulate in lysosomes laden with $\mathrm{Ca}^{2+}$ and sphingomyelin (Bae, Patel et al., 2014). Interestingly, activation of TRPML1 cleared both the amyloid accumulation as well as the accumulation of sphingomyelin in cultured neurons expressing the HIV coat protein gp120. Although this is the opposite of what we found in FAD, the cellular phenotypes in part resemble NPC disease, where there is also an accumulation of sphingomyelin. Furthermore, NPC1, sometimes referred to as a form of childhood dementia owing to the earliest recorded presence of neurofibrillary tangles, hyerphosphorylated tau and accumulation of amyloid- $\beta_{40-42}$ in post-mortem tissue samples from young patients (Saito et al., 2002, Suzuki, Parker et al., 1995), also has altered $\mathrm{Ca}^{2+}$ release from TRPML1(Shen et al., 2012). This is presumably in response to reduced late endosome/lysosomal $\mathrm{Ca}^{2+}$ levels rather than either a change in lysosomal $\mathrm{pH}$ (not present in NPC), or an effect of sphingomyelin on TRPML1 function as discussed above. Whether or not the reduced activity of TRPML1 in NPC disease is in any way involved with the cellular hallmarks of $\mathrm{AD}$ remains to be elucidated but there is clearly a role for altered lysosomal $\mathrm{Ca}^{2+}$ in certain forms of $\mathrm{AD}$, demonstrating whether this feature also occurs in sporadic $\mathrm{AD}$ may be crucial for the development of any therapeutic strategy in this area.

To conclude, changes in lysosomal $\mathrm{Ca}^{2+}$ are becoming increasingly prevalent in various forms of both common and rare forms of neurodegenerative disease. The development of clinically approved therapeutics in the future that can target and alter lysosomal $\mathrm{Ca}^{2+}$ signalling may be an important avenue for ultimately treating these diseases.

\section{Acknowledgements}

The author would like to thank Dr. Helen Waller-Evans for assistance with the figures and for proof reading the article. Lysosomal $\mathrm{Ca}^{2+}$ and neurodegeneration research in the Lloyd-Evans lab has been supported from several sources including the Research Councils UK (fellowship to ELE), MRC In Vivo skills award, Alzheimer's Research UK, Action Medical Research, the Niemann-Pick Research Foundation, the UK Niemann-Pick Disease Group and Sport Aiding Medical Research for Kids. 


\section{References}

Altarescu G, Sun M, Moore DF, Smith JA, Wiggs EA, Solomon BI, Patronas NJ, Frei KP, Gupta S, Kaneski CR, Quarrell OW, et al. The neurogenetics of mucolipidosis type IV. Neurology. 2002; 59:306-13. [PubMed: 12182165]

Ambrosi G, Ghezzi C, Zangaglia R, Levandis G, Pacchetti C, Blandini F. Ambroxol-induced rescue of defective glucocerebrosidase is associated with increased LIMP-2 and saposin C levels in GBA1 mutant Parkinson's disease cells. Neurobiol Dis. 2015; 82:235-42. [PubMed: 26094596]

Avrahami L, Farfara D, Shaham-Kol M, Vassar R, Frenkel D, Eldar-Finkelman H. Inhibition of glycogen synthase kinase-3 ameliorates beta-amyloid pathology and restores lysosomal acidification and mammalian target of rapamycin activity in the Alzheimer disease mouse model: in vivo and in vitro studies. J Biol Chem. 2013; 288:1295-306. [PubMed: 23155049]

Bach G. Mucolipidosis type IV. Mol Genet Metab. 2001; 73:197-203. [PubMed: 11461186]

Bach G, Chen CS, Pagano RE. Elevated lysosomal pH in Mucolipidosis type IV cells. Clin Chim Acta. 1999; 280:173-9. [PubMed: 10090534]

Bach G, Zeigler M, Kohn G. Biochemical investigations of cultured amniotic fluid cells in mucolipidosis type IV. Clin Chim Acta. 1980; 106:121-8. [PubMed: 6447555]

Bach G, Ziegler M, Kohn G, Cohen MM. Mucopolysaccharide accumulation in cultured skin fibroblasts derived from patients with mucolipidosis IV. Am J Hum Genet. 1977; 29:610-8. [PubMed: 145180]

Bae M, Patel N, Xu H, Lee M, Tominaga-Yamanaka K, Nath A, Geiger J, Gorospe M, Mattson MP, Haughey NJ. Activation of TRPML1 clears intraneuronal Abeta in preclinical models of HIV infection. J Neurosci. 2014; 34:11485-503. [PubMed: 25143627]

Bargal R, Avidan N, Ben-Asher E, Olender Z, Zeigler M, Frumkin A, Raas-Rothschild A, Glusman G, Lancet D, Bach G. Identification of the gene causing mucolipidosis type IV. Nat Genet. 2000; 26:118-23. [PubMed: 10973263]

Bargal R, Bach G. Phospholipids accumulation in mucolipidosis IV cultured fibroblasts. J Inherit Metab Dis. 1988; 11:144-50. [PubMed: 3139925]

Bargal R, Bach G. Phosphatidylcholine storage in mucolipidosis IV. Clin Chim Acta. 1989; 181:16774. [PubMed: 2736780]

Berridge MJ, Lipp P, Bootman MD. The versatility and universality of calcium signalling. Nat Rev Mol Cell Biol. 2000; 1:11-21. [PubMed: 11413485]

Bilmen JG, Khan SZ, Javed MH, Michelangeli F. Inhibition of the SERCA Ca2+ pumps by curcumin. Curcumin putatively stabilizes the interaction between the nucleotide-binding and phosphorylation domains in the absence of ATP. Eur J Biochem. 2001; 268:6318-27. [PubMed: 11733029]

Biskup S, Moore DJ, Celsi F, Higashi S, West AB, Andrabi SA, Kurkinen K, Yu SW, Savitt JM, Waldvogel HJ, Faull RL, et al. Localization of LRRK2 to membranous and vesicular structures in mammalian brain. Ann Neurol. 2006; 60:557-69. [PubMed: 17120249]

Borbon IA, Hillman Z, Duran E Jr, Kiela PR, Frautschy SA, Erickson RP. Lack of efficacy of curcumin on neurodegeneration in the mouse model of Niemann-Pick C1. Pharmacol Biochem Behav. 2012; 101:125-31. [PubMed: 22202649]

Brailoiu E, Churamani D, Cai X, Schrlau MG, Brailoiu GC, Gao X, Hooper R, Boulware MJ, Dun NJ, Marchant JS, Patel S. Essential requirement for two-pore channel 1 in NAADP-mediated calcium signaling. J Cell Biol. 2009; 186:201-9. [PubMed: 19620632]

Brini M, Carafoli E. The plasma membrane $\mathrm{Ca}(2)+$ ATPase and the plasma membrane sodium calcium exchanger cooperate in the regulation of cell calcium. Cold Spring Harb Perspect Biol. 2011; 3

Bygrave FL, Benedetti A. What is the concentration of calcium ions in the endoplasmic reticulum? Cell Calcium. 1996; 19:547-51. [PubMed: 8842522]

Calcraft PJ, Ruas M, Pan Z, Cheng X, Arredouani A, Hao X, Tang J, Rietdorf K, Teboul L, Chuang $\mathrm{KT}$, Lin P, et al. NAADP mobilizes calcium from acidic organelles through two-pore channels. Nature. 2009; 459:596-600. [PubMed: 19387438]

Cantiello HF, Montalbetti N, Goldmann WH, Raychowdhury MK, Gonzalez-Perrett S, Timpanaro GA, Chasan B. Cation channel activity of mucolipin-1: the effect of calcium. Pflugers Arch. 2005; 451:304-12. [PubMed: 16133264] 
Cao Q, Zhong XZ, Zou Y, Zhang Z, Toro L, Dong XP. BK Channels Alleviate Lysosomal Storage Diseases by Providing Positive Feedback Regulation of Lysosomal Ca2+ Release. Developmental cell. 2015; 33:427-41. [PubMed: 25982675]

Cao Y, Espinola JA, Fossale E, Massey AC, Cuervo AM, MacDonald ME, Cotman SL. Autophagy is disrupted in a knock-in mouse model of juvenile neuronal ceroid lipofuscinosis. J Biol Chem. 2006; 281:20483-93. [PubMed: 16714284]

Coen K, Flannagan RS, Baron S, Carraro-Lacroix LR, Wang D, Vermeire W, Michiels C, Munck S, Baert V, Sugita S, Wuytack F, et al. Lysosomal calcium homeostasis defects, not proton pump defects, cause endo-lysosomal dysfunction in PSEN-deficient cells. J Cell Biol. 2012; 198:23-35. [PubMed: 22753898]

Coffey EE, Beckel JM, Laties AM, Mitchell CH. Lysosomal alkalization and dysfunction in human fibroblasts with the Alzheimer's disease-linked presenilin 1 A246E mutation can be reversed with cAMP. Neuroscience. 2014; 263:111-24. [PubMed: 24418614]

Colina C, Cervino V, Benaim G. Ceramide and sphingosine have an antagonistic effect on the plasmamembrane Ca2+-ATPase from human erythrocytes. Biochem J. 2002; 362:247-51. [PubMed: 11829762]

Cox TM, Cachon-Gonzalez MB. The cellular pathology of lysosomal diseases. J Pathol. 2012; 226:241-54. [PubMed: 21990005]

Cuajungco MP, Basilio LC, Silva J, Hart T, Tringali J, Chen CC, Biel M, Grimm C. Cellular zinc levels are modulated by TRPML1-TMEM163 interaction. Traffic. 2014; 15:1247-65. [PubMed: 25130899]

Currinn H, Guscott B, Balklava Z, Rothnie A, Wassmer T. APP controls the formation of PI $(3,5) \mathrm{P}(2)$ vesicles through its binding of the PIKfyve complex. Cell Mol Life Sci. 2016; 73:393-408. [PubMed: 26216398]

Chandrachud U, Walker MW, Simas AM, Heetveld S, Petcherski A, Klein M, Oh H, Wolf P, Zhao WN, Norton S, Haggarty SJ, et al. Unbiased Cell-based Screening in a Neuronal Cell Model of Batten Disease Highlights an Interaction between Ca2+ Homeostasis, Autophagy, and CLN3 Protein Function. J Biol Chem. 2015; 290:14361-80. [PubMed: 25878248]

Chen CS, Bach G, Pagano RE. Abnormal transport along the lysosomal pathway in mucolipidosis, type IV disease. Proc Natl Acad Sci U S A. 1998; 95:6373-8. [PubMed: 9600972]

Chiba Y, Komori H, Takei S, Hasegawa-Ishii S, Kawamura N, Adachi K, Nanba E, Hosokawa M, Enokido Y, Kouchi Z, Yoshida F, et al. Niemann-Pick disease type $\mathrm{C} 1$ predominantly involving the frontotemporal region, with cortical and brainstem Lewy bodies: an autopsy case. Neuropathology. 2014; 34:49-57. [PubMed: 23711246]

Choi L, Vernon J, Kopach O, Minett MS, Mills K, Clayton PT, Meert T, Wood JN. The Fabry diseaseassociated lipid Lyso-Gb3 enhances voltage-gated calcium currents in sensory neurons and causes pain. Neurosci Lett. 2015; 594:163-8. [PubMed: 25697597]

Christensen KA, Myers JT, Swanson JA. pH-dependent regulation of lysosomal calcium in macrophages. J Cell Sci. 2002; 115:599-607. [PubMed: 11861766]

Chu Y, Dodiya H, Aebischer P, Olanow CW, Kordower JH. Alterations in lysosomal and proteasomal markers in Parkinson's disease: relationship to alpha-synuclein inclusions. Neurobiol Dis. 2009; 35:385-98. [PubMed: 19505575]

Churchill GC, Okada Y, Thomas JM, Genazzani AA, Patel S, Galione A. NAADP mobilizes Ca(2+) from reserve granules, lysosome-related organelles, in sea urchin eggs. Cell. 2002; 111:703-8. [PubMed: 12464181]

Dauer W, Przedborski S. Parkinson's disease: mechanisms and models. Neuron. 2003; 39:889-909. [PubMed: 12971891]

Davies JP, Chen FW, Ioannou YA. Transmembrane molecular pump activity of Niemann-Pick C1 protein. Science. 2000; 290:2295-8. [PubMed: 11125140]

de Rijk MC, Launer LJ, Berger K, Breteler MM, Dartigues JF, Baldereschi M, Fratiglioni L, Lobo A, Martinez-Lage J, Trenkwalder C, Hofman A. Prevalence of Parkinson's disease in Europe: A collaborative study of population-based cohorts. Neurologic Diseases in the Elderly Research Group. Neurology. 2000; 54:S21-3. 
Dellis O, Arbabian A, Brouland JP, Kovacs T, Rowe M, Chomienne C, Joab I, Papp B. Modulation of B-cell endoplasmic reticulum calcium homeostasis by Epstein-Barr virus latent membrane protein-1. Mol Cancer. 2009; 8:59. [PubMed: 19650915]

Dermentzaki G, Dimitriou E, Xilouri M, Michelakakis H, Stefanis L. Loss of beta-glucocerebrosidase activity does not affect alpha-synuclein levels or lysosomal function in neuronal cells. PLoS One. 2013; 8:e60674. [PubMed: 23580063]

Dickinson GD, Churchill GC, Brailoiu E, Patel S. Deviant nicotinic acid adenine dinucleotide phosphate (NAADP)-mediated Ca2+ signaling upon lysosome proliferation. J Biol Chem. 2010; 285:13321-5. [PubMed: 20231291]

Dodson MW, Zhang T, Jiang C, Chen S, Guo M. Roles of the Drosophila LRRK2 homolog in Rab7dependent lysosomal positioning. Hum Mol Genet. 2012; 21:1350-63. [PubMed: 22171073]

Dong XP, Cheng X, Mills E, Delling M, Wang F, Kurz T, Xu H. The type IV mucolipidosis-associated protein TRPML1 is an endolysosomal iron release channel. Nature. 2008; 455:992-6. [PubMed: 18794901]

Dong XP, Shen D, Wang X, Dawson T, Li X, Zhang Q, Cheng X, Zhang Y, Weisman LS, Delling M, $\mathrm{Xu} \mathrm{H}$. PI(3,5)P(2) controls membrane trafficking by direct activation of mucolipin $\mathrm{Ca}(2+)$ release channels in the endolysosome. Nat Commun. 2010; 1:38. [PubMed: 20802798]

Efthymiou AG, Steiner J, Pavan WJ, Wincovitch S, Larson DM, Porter FD, Rao MS, Malik N. Rescue of an in vitro neuron phenotype identified in Niemann-Pick disease, type $\mathrm{C} 1$ induced pluripotent stem cell-derived neurons by modulating the WNT pathway and calcium signaling. Stem Cells Transl Med. 2015; 4:230-8. [PubMed: 25637190]

Ezaki J, Himeno M, Kato K. Purification and characterization of ( $\mathrm{Ca} 2+-\mathrm{Mg} 2+)$-ATPase in rat liver lysosomal membranes. J Biochem. 1992; 112:33-9. [PubMed: 1331035]

Fois G, Hobi N, Felder E, Ziegler A, Miklavc P, Walther P, Radermacher P, Haller T, Dietl P. A new role for an old drug: Ambroxol triggers lysosomal exocytosis via $\mathrm{pH}$-dependent $\mathrm{Ca}(2)(+)$ release from acidic $\mathrm{Ca}(2)(+)$ stores. Cell Calcium. 2015; 58:628-37. [PubMed: 26560688]

Freundt EC, Czapiga M, Lenardo MJ. Photoconversion of Lysotracker Red to a green fluorescent molecule. Cell Res. 2007; 17:956-8. [PubMed: 17893709]

Galione A, Churchill GC. Interactions between calcium release pathways: multiple messengers and multiple stores. Cell Calcium. 2002; 32:343-54. [PubMed: 12543094]

Gan M, Moussaud S, Jiang P, McLean PJ. Extracellular ATP induces intracellular alpha-synuclein accumulation via P2X1 receptor-mediated lysosomal dysfunction. Neurobiol Aging. 2015; 36:1209-20. [PubMed: 25480524]

Garrity AG, Wang W, Collier CM, Levey SA, Gao Q, Xu H. The endoplasmic reticulum, not the pH gradient, drives calcium refilling of lysosomes. Elife. 2016; 5

Gerasimenko JV, Tepikin AV, Petersen OH, Gerasimenko OV. Calcium uptake via endocytosis with rapid release from acidifying endosomes. Curr Biol. 1998; 8:1335-8. [PubMed: 9843688]

Ginzburg L, Futerman AH. Defective calcium homeostasis in the cerebellum in a mouse model of Niemann-Pick A disease. J Neurochem. 2005; 95:1619-28. [PubMed: 16277603]

Gomez-Suaga P, Luzon-Toro B, Churamani D, Zhang L, Bloor-Young D, Patel S, Woodman PG, Churchill GC, Hilfiker S. Leucine-rich repeat kinase 2 regulates autophagy through a calciumdependent pathway involving NAADP. Hum Mol Genet. 2012; 21:511-25. [PubMed: 22012985]

Gordon PB, Holen I, Fosse M, Rotnes JS, Seglen PO. Dependence of hepatocytic autophagy on intracellularly sequestered calcium. J Biol Chem. 1993; 268:26107-12. [PubMed: 8253727]

Henry AG, Aghamohammadzadeh S, Samaroo H, Chen Y, Mou K, Needle E, Hirst WD. Pathogenic LRRK2 mutations, through increased kinase activity, produce enlarged lysosomes with reduced degradative capacity and increase ATP13A2 expression. Hum Mol Genet. 2015; 24:6013-28. [PubMed: 26251043]

Hockey LN, Kilpatrick BS, Eden ER, Lin-Moshier Y, Brailoiu GC, Brailoiu E, Futter CE, Schapira AH, Marchant JS, Patel S. Dysregulation of lysosomal morphology by pathogenic LRRK2 is corrected by TPC2 inhibition. J Cell Sci. 2015; 128:232-8. [PubMed: 25416817]

Hoglinger D, Haberkant P, Aguilera-Romero A, Riezman H, Porter FD, Platt FM, Galione A, Schultz C. Intracellular sphingosine releases calcium from lysosomes. Elife. 2015; 4 
Huang P, Zou Y, Zhong XZ, Cao Q, Zhao K, Zhu MX, Murrell-Lagnado R, Dong XP. P2X4 forms functional ATP-activated cation channels on lysosomal membranes regulated by luminal $\mathrm{pH}$. J Biol Chem. 2014; 289:17658-67. [PubMed: 24817123]

Im DS, Heise CE, Nguyen T, O'Dowd BF, Lynch KR. Identification of a molecular target of psychosine and its role in globoid cell formation. J Cell Biol. 2001; 153:429-34. [PubMed: 11309421]

Ioannou YA. Guilty until proven innocent: the case of NPC1 and cholesterol. Trends Biochem Sci. 2005; 30:498-505. [PubMed: 16054367]

Ivanova EA, Elmonem MA, Bongaerts I, Luyten T, Missiaen L, van den Heuvel LP, Levtchenko EN, Bultynck $\mathrm{G}$. $\mathrm{Ca}(2+)$ signalling in human proximal tubular epithelial cells deficient for cystinosin. Cell Calcium. 2016; 60:282-7. [PubMed: 27451386]

Jha A, Ahuja M, Patel S, Brailoiu E, Muallem S. Convergent regulation of the lysosomal two-pore channel-2 by $\operatorname{Mg}(2)(+)$, NAADP, PI(3,5)P(2) and multiple protein kinases. EMBO J. 2014; 33:501-11. [PubMed: 24502975]

Jones HC, Keep RF. Brain fluid calcium concentration and response to acute hypercalcaemia during development in the rat. J Physiol. 1988; 402:579-93. [PubMed: 3236250]

Kagedal K, Zhao M, Svensson I, Brunk UT. Sphingosine-induced apoptosis is dependent on lysosomal proteases. Biochem J. 2001; 359:335-43. [PubMed: 11583579]

Kaufmann AM, Krise JP. Niemann-Pick C1 functions in regulating lysosomal amine content. J Biol Chem. 2008; 283:24584-93. [PubMed: 18591242]

Kilpatrick BS, Eden ER, Schapira AH, Futter CE, Patel S. Direct mobilisation of lysosomal Ca2+ triggers complex Ca2+ signals. J Cell Sci. 2013; 126:60-6. [PubMed: 23108667]

Kilpatrick BS, Magalhaes J, Beavan MS, McNeill A, Gegg ME, Cleeter MW, Bloor-Young D, Churchill GC, Duchen MR, Schapira AH, Patel S. Endoplasmic reticulum and lysosomal Ca(2)(+) stores are remodelled in GBA1-linked Parkinson disease patient fibroblasts. Cell Calcium. 2016a; 59:12-20. [PubMed: 26691915]

Kilpatrick BS, Yates E, Grimm C, Schapira AH, Patel S. Endo-lysosomal TRP mucolipin-1 channels trigger global ER Ca2+ release and Ca2+ influx. J Cell Sci. 2016b; 129:3859-3867. [PubMed: 27577094]

Klemper MS. An adenosine triphosphate-dependent calcium uptake pump in human neutrophil lysosomes. J Clin Invest. 1985; 76:303-10. [PubMed: 3926820]

Korkotian E, Schwarz A, Pelled D, Schwarzmann G, Segal M, Futerman AH. Elevation of intracellular glucosylceramide levels results in an increase in endoplasmic reticulum density and in functional calcium stores in cultured neurons. J Biol Chem. 1999; 274:21673-8. [PubMed: 10419477]

La Rovere RM, Roest G, Bultynck G, Parys JB. Intracellular $\mathrm{Ca}(2+)$ signaling and $\mathrm{Ca}(2+)$ microdomains in the control of cell survival, apoptosis and autophagy. Cell Calcium. 2016; 60:7487. [PubMed: 27157108]

Lange I, Yamamoto S, Partida-Sanchez S, Mori Y, Fleig A, Penner R. TRPM2 functions as a lysosomal Ca2+-release channel in beta cells. Science signaling. 2009; 2:ra23. [PubMed: 19454650]

Lai BC, Marion SA, Teschke K, Tsui JK. Occupational and environmental risk factors for Parkinson's disease. Parkinsonism Relat Disord. 2002; 8:297-309. [PubMed: 15177059]

Lamason RL, Mohideen MA, Mest JR, Wong AC, Norton HL, Aros MC, Jurynec MJ, Mao X, Humphreville VR, Humbert JE, Sinha S, et al. SLC24A5, a putative cation exchanger, affects pigmentation in zebrafish and humans. Science. 2005; 310:1782-6. [PubMed: 16357253]

LaPlante JM, Falardeau J, Sun M, Kanazirska M, Brown EM, Slaugenhaupt SA, Vassilev PM. Identification and characterization of the single channel function of human mucolipin-1 implicated in mucolipidosis type IV, a disorder affecting the lysosomal pathway. FEBS Lett. 2002; 532:1837. [PubMed: 12459486]

Lee H, Lee JK, Min WK, Bae JH, He X, Schuchman EH, Bae JS, Jin HK. Bone marrow-derived mesenchymal stem cells prevent the loss of Niemann-Pick type $\mathrm{C}$ mouse Purkinje neurons by correcting sphingolipid metabolism and increasing sphingosine-1-phosphate. Stem Cells. 2010a; 28:821-31. [PubMed: 20201063] 
Lee H, Lee JK, Park MH, Hong YR, Marti HH, Kim H, Okada Y, Otsu M, Seo EJ, Park JH, Bae JH, et al. Pathological roles of the VEGF/SphK pathway in Niemann-Pick type C neurons. Nat Commun. 2014; 5:5514. [PubMed: 25417698]

Lee JH, McBrayer MK, Wolfe DM, Haslett LJ, Kumar A, Sato Y, Lie PP, Mohan P, Coffey EE, Kompella U, Mitchell CH, et al. Presenilin 1 Maintains Lysosomal $\mathrm{Ca}(2+)$ Homeostasis via TRPML1 by Regulating vATPase-Mediated Lysosome Acidification. Cell reports. 2015; 12:1430 44. [PubMed: 26299959]

Lee JH, Yu WH, Kumar A, Lee S, Mohan PS, Peterhoff CM, Wolfe DM, Martinez-Vicente M, Massey AC, Sovak G, Uchiyama Y, et al. Lysosomal proteolysis and autophagy require presenilin 1 and are disrupted by Alzheimer-related PS1 mutations. Cell. 2010b; 141:1146-58. [PubMed: 20541250]

Lelouvier B, Puertollano R. Mucolipin-3 regulates luminal calcium, acidification, and membrane fusion in the endosomal pathway. J Biol Chem. 2011; 286:9826-32. [PubMed: 21245134]

Lemons RM, Thoene JG. Mediated calcium transport by isolated human fibroblast lysosomes. J Biol Chem. 1991; 266:14378-82. [PubMed: 1830585]

Lim JA, Li L, Kakhlon O, Myerowitz R, Raben N. Defects in calcium homeostasis and mitochondria can be reversed in Pompe disease. Autophagy. 2015; 11:385-402. [PubMed: 25758767]

Lin-Moshier Y, Keebler MV, Hooper R, Boulware MJ, Liu X, Churamani D, Abood ME, Walseth TF, Brailoiu E, Patel S, Marchant JS. The Two-pore channel (TPC) interactome unmasks isoformspecific roles for TPCs in endolysosomal morphology and cell pigmentation. Proc Natl Acad Sci U S A. 2014; 111:13087-92. [PubMed: 25157141]

Lopez JJ, Jardin I, Bobe R, Pariente JA, Enouf J, Salido GM, Rosado JA. STIM1 regulates acidic Ca2+ store refilling by interaction with SERCA3 in human platelets. Biochem Pharmacol. 2008; 75:2157-64. [PubMed: 18439569]

Lopez Sanjurjo CI, Tovey SC, Taylor CW. Rapid recycling of Ca2+ between IP3-sensitive stores and lysosomes. PLoS One. 2014; 9:e111275. [PubMed: 25337829]

Lopez-Sanjurjo CI, Tovey SC, Prole DL, Taylor CW. Lysosomes shape Ins(1,4,5)P3-evoked Ca2+ signals by selectively sequestering $\mathrm{Ca} 2+$ released from the endoplasmic reticulum. J Cell Sci. 2013; 126:289-300. [PubMed: 23097044]

Lu F, Liang Q, Abi-Mosleh L, Das A, De Brabander JK, Goldstein JL, Brown MS. Identification of NPC1 as the target of U18666A, an inhibitor of lysosomal cholesterol export and Ebola infection. Elife. 2015:4.

Lu Y, Hao BX, Graeff R, Wong CW, Wu WT, Yue J. Two pore channel 2 (TPC2) inhibits autophagosomal-lysosomal fusion by alkalinizing lysosomal pH. J Biol Chem. 2013; 288:2424763. [PubMed: 23836916]

Luzio JP, Parkinson MD, Gray SR, Bright NA. The delivery of endocytosed cargo to lysosomes. Biochem Soc Trans. 2009; 37:1019-21. [PubMed: 19754443]

Luzio JP, Pryor PR, Bright NA. Lysosomes: fusion and function. Nat Rev Mol Cell Biol. 2007; 8:62232. [PubMed: 17637737]

Lloyd-Evans E, Haslett LJ. The lysosomal storage disease continuum with ageing-related neurodegenerative disease. Ageing Res Rev. 2016a; 32:104-121. [PubMed: 27516378]

Lloyd-Evans E, Haslett LJ. The lysosomal storage disease continuum with ageing-related neurodegenerative disease. Ageing Res Rev. 2016b

Lloyd-Evans E, Morgan AJ, He X, Smith DA, Elliot-Smith E, Sillence DJ, Churchill GC, Schuchman $\mathrm{EH}$, Galione A, Platt FM. Niemann-Pick disease type $\mathrm{C} 1$ is a sphingosine storage disease that causes deregulation of lysosomal calcium. Nat Med. 2008; 14:1247-55. [PubMed: 18953351]

Lloyd-Evans E, Pelled D, Riebeling C, Bodennec J, de-Morgan A, Waller H, Schiffmann R, Futerman AH. Glucosylceramide and glucosylsphingosine modulate calcium mobilization from brain microsomes via different mechanisms. J Biol Chem. 2003a; 278:23594-9. [PubMed: 12709427]

Lloyd-Evans E, Pelled D, Riebeling C, Futerman AH. Lyso-glycosphingolipids mobilize calcium from brain microsomes via multiple mechanisms. Biochem J. 2003b; 375:561-5. [PubMed: 12917012]

Lloyd-Evans E, Platt FM. Lipids on Trial: The Search for the Offending Metabolite in Niemann-Pick type C Disease. Traffic. 2010; 11:419-428. [PubMed: 20059748] 
Lloyd-Evans E, Platt FM. Lysosomal $\mathrm{Ca}(2+)$ homeostasis: role in pathogenesis of lysosomal storage diseases. Cell Calcium. 2011; 50:200-5. [PubMed: 21724254]

Lloyd-Evans E, Waller-Evans H, Peterneva K, Platt FM. Endolysosomal calcium regulation and disease. Biochem Soc Trans. 2010; 38:1458-64. [PubMed: 21118107]

MacLeod DA, Rhinn H, Kuwahara T, Zolin A, Di Paolo G, McCabe BD, Marder KS, Honig LS, Clark LN, Small SA, Abeliovich A. RAB7L1 interacts with LRRK2 to modify intraneuronal protein sorting and Parkinson's disease risk. Neuron. 2013; 77:425-39. [PubMed: 23395371]

Marin I. The Parkinson disease gene LRRK2: evolutionary and structural insights. Mol Biol Evol. 2006; 23:2423-33. [PubMed: 16966681]

Mayran N, Parton RG, Gruenberg J. Annexin II regulates multivesicular endosome biogenesis in the degradation pathway of animal cells. Embo J. 2003; 22:3242-53. [PubMed: 12839987]

McGlinchey RP, Lee JC. Cysteine cathepsins are essential in lysosomal degradation of alphasynuclein. Proc Natl Acad Sci U S A. 2015; 112:9322-7. [PubMed: 26170293]

Medina DL, Ballabio A. Lysosomal calcium regulates autophagy. Autophagy. 2015; 11:970-1. [PubMed: 26000950]

Medina DL, Di Paola S, Peluso I, Armani A, De Stefani D, Venditti R, Montefusco S, Scotto-Rosato A, Prezioso C, Forrester A, Settembre C, et al. Lysosomal calcium signalling regulates autophagy through calcineurin and TFEB. Nat Cell Biol. 2015; 17:288-99. [PubMed: 25720963]

Medina DL, Fraldi A, Bouche V, Annunziata F, Mansueto G, Spampanato C, Puri C, Pignata A, Martina JA, Sardiello M, Palmieri M, et al. Transcriptional activation of lysosomal exocytosis promotes cellular clearance. Developmental cell. 2011; 21:421-30. [PubMed: 21889421]

Mekahli D, Bultynck G, Parys JB, De Smedt H, Missiaen L. Endoplasmic-reticulum calcium depletion and disease. Cold Spring Harb Perspect Biol. 2011:3.

Melchionda M, Pittman JK, Mayor R, Patel S. Ca2+/H+ exchange by acidic organelles regulates cell migration in vivo. J Cell Biol. 2016; 212:803-13. [PubMed: 27002171]

Millat G, Marcais C, Tomasetto C, Chikh K, Fensom AH, Harzer K, Wenger DA, Ohno K, Vanier MT. Niemann-Pick C1 disease: correlations between NPC1 mutations, levels of NPC1 protein, and phenotypes emphasize the functional significance of the putative sterol-sensing domain and of the cysteine-rich luminal loop. Am J Hum Genet. 2001; 68:1373-85. [PubMed: 11333381]

Mishra S, Palanivelu K. The effect of curcumin (turmeric) on Alzheimer's disease: An overview. Ann Indian Acad Neurol. 2008; 11:13-9. [PubMed: 19966973]

Morgan AJ, Davis LC, Wagner SK, Lewis AM, Parrington J, Churchill GC, Galione A. Bidirectional $\mathrm{Ca}(2)(+)$ signaling occurs between the endoplasmic reticulum and acidic organelles. J Cell Biol. 2013; 200:789-805. [PubMed: 23479744]

Morgan AJ, Galione A. NAADP induces $\mathrm{pH}$ changes in the lumen of acidic $\mathrm{Ca} 2+$ stores. Biochem J. 2007; 402:301-10. [PubMed: 17117921]

Morgan AJ, Platt FM, Lloyd-Evans E, Galione A. Molecular mechanisms of endolysosomal Ca2+ signalling in health and disease. Biochem J. 2011; 439:349-74. [PubMed: 21992097]

Murphy KE, Gysbers AM, Abbott SK, Tayebi N, Kim WS, Sidransky E, Cooper A, Garner B, Halliday GM. Reduced glucocerebrosidase is associated with increased alpha-synuclein in sporadic Parkinson's disease. Brain. 2014; 137:834-48. [PubMed: 24477431]

Naylor E, Arredouani A, Vasudevan SR, Lewis AM, Parkesh R, Mizote A, Rosen D, Thomas JM, Izumi M, Ganesan A, Galione A, et al. Identification of a chemical probe for NAADP by virtual screening. Nat Chem Biol. 2009; 5:220-6. [PubMed: 19234453]

Nicoli ER, Al Eisa N, Cluzeau CV, Wassif CA, Gray J, Burkert KR, Smith DA, Morris L, Cologna SM, Peer CJ, Sissung TM, et al. Defective Cytochrome P450-Catalysed Drug Metabolism in Niemann-Pick Type C Disease. PLoS One. 2016; 11:e0152007. [PubMed: 27019000]

Pandol SJ, Schoeffield-Payne MS, Gukovskaya AS, Rutherford RE. Sphingosine regulates Ca(2+)ATPase and reloading of intracellular $\mathrm{Ca} 2+$ stores in the pancreatic acinar cell. Biochim Biophys Acta. 1994; 1195:45-50. [PubMed: 7918564]

Patel S, Cai X. Evolution of acidic $\mathrm{Ca}(2)(+)$ stores and their resident $\mathrm{Ca}(2)(+)$-permeable channels. Cell Calcium. 2015; 57:222-30. [PubMed: 25591931] 
Patterson MC, Hendriksz CJ, Walterfang M, Sedel F, Vanier MT, Wijburg F, Group N-CGW. Recommendations for the diagnosis and management of Niemann-Pick disease type C: an update. Mol Genet Metab. 2012; 106:330-44. [PubMed: 22572546]

Patterson MC, Mengel E, Wijburg FA, Muller A, Schwierin B, Drevon H, Vanier MT, Pineda M. Disease and patient characteristics in NP-C patients: findings from an international disease registry. Orphanet J Rare Dis. 2013; 8:12. [PubMed: 23324478]

Pelled D, Lloyd-Evans E, Riebeling C, Jeyakumar M, Platt FM, Futerman AH. Inhibition of calcium uptake via the sarco/endoplasmic reticulum Ca2+-ATPase in a mouse model of Sandhoff disease and prevention by treatment with N-butyldeoxynojirimycin. J Biol Chem. 2003; 278:29496-501. [PubMed: 12756243]

Pelled D, Trajkovic-Bodennec S, Lloyd-Evans E, Sidransky E, Schiffmann R, Futerman AH. Enhanced calcium release in the acute neuronopathic form of Gaucher disease. Neurobiol Dis. 2005; 18:838. [PubMed: 15649698]

Pereira VG, Gazarini ML, Rodrigues LC, da Silva FH, Han SW, Martins AM, Tersariol IL, D'Almeida V. Evidence of lysosomal membrane permeabilization in mucopolysaccharidosis type I: rupture of calcium and proton homeostasis. J Cell Physiol. 2010; 223:335-42. [PubMed: 20082302]

Pihlstrom L, Rengmark A, Bjornara KA, Dizdar N, Fardell C, Forsgren L, Holmberg B, Larsen JP, Linder J, Nissbrandt H, Tysnes OB, et al. Fine mapping and resequencing of the PARK16 locus in Parkinson's disease. J Hum Genet. 2015; 60:357-62. [PubMed: 25855069]

Piper RC, Luzio JP. CUPpling calcium to lysosomal biogenesis. Trends Cell Biol. 2004; 14:471-3. [PubMed: 15350973]

Pitt SJ, Funnell TM, Sitsapesan M, Venturi E, Rietdorf K, Ruas M, Ganesan A, Gosain R, Churchill GC, Zhu MX, Parrington J, et al. TPC2 is a novel NAADP-sensitive Ca2+ release channel, operating as a dual sensor of luminal pH and Ca2+ J Biol Chem. 2010; 285:35039-46. [PubMed: 20720007]

Pitt SJ, Lam AK, Rietdorf K, Galione A, Sitsapesan R. Reconstituted human TPC1 is a protonpermeable ion channel and is activated by NAADP or Ca2+ Science signaling. 2014; 7:ra46. [PubMed: 24847115]

Planchard MS, Exley SE, Morgan SE, Rangachari V. Dopamine-induced alpha-synuclein oligomers show self- and cross-propagation properties. Protein Sci. 2014; 23:1369-79. [PubMed: 25044276]

Platt FM, Boland B, van der Spoel AC. The cell biology of disease: lysosomal storage disorders: the cellular impact of lysosomal dysfunction. J Cell Biol. 2012; 199:723-34. [PubMed: 23185029]

Platt FM, Jeyakumar M. Substrate reduction therapy. Acta Paediatr Suppl. 2008; 97:88-93.

Pryor PR, Mullock BM, Bright NA, Gray SR, Luzio JP. The role of intraorganellar $\mathrm{Ca}(2+)$ in late endosome-lysosome heterotypic fusion and in the reformation of lysosomes from hybrid organelles. J Cell Biol. 2000; 149:1053-62. [PubMed: 10831609]

Raychowdhury MK, Gonzalez-Perrett S, Montalbetti N, Timpanaro GA, Chasan B, Goldmann WH, Stahl S, Cooney A, Goldin E, Cantiello HF. Molecular pathophysiology of mucolipidosis type IV: pH dysregulation of the mucolipin-1 cation channel. Hum Mol Genet. 2004; 13:617-27. [PubMed: 14749347]

Ron I, Horowitz M. Intracellular cholesterol modifies the ERAD of glucocerebrosidase in Gaucher disease patients. Mol Genet Metab. 2008; 93:426-36. [PubMed: 18160322]

Rothaug M, Zunke F, Mazzulli JR, Schweizer M, Altmeppen H, Lullmann-Rauch R, Kallemeijn WW, Gaspar P, Aerts JM, Glatzel M, Saftig P, et al. LIMP-2 expression is critical for betaglucocerebrosidase activity and alpha-synuclein clearance. Proc Natl Acad Sci U S A. 2014; 111:15573-8. [PubMed: 25316793]

Ruas M, Davis LC, Chen CC, Morgan AJ, Chuang KT, Walseth TF, Grimm C, Garnham C, Powell T, Platt N, Platt FM, et al. Expression of $\mathrm{Ca}(2)(+)$-permeable two-pore channels rescues NAADP signalling in TPC-deficient cells. EMBO J. 2015; 34:1743-58. [PubMed: 25872774]

Ruas M, Rietdorf K, Arredouani A, Davis LC, Lloyd-Evans E, Koegel H, Funnell TM, Morgan AJ, Ward JA, Watanabe K, Cheng X, et al. Purified TPC Isoforms Form NAADP Receptors with Distinct Roles for $\mathrm{Ca}(2+)$ Signaling and Endolysosomal Trafficking. Curr Biol. 2010 
Saftig P, Klumperman J. Lysosome biogenesis and lysosomal membrane proteins: trafficking meets function. Nat Rev Mol Cell Biol. 2009; 10:623-35. [PubMed: 19672277]

Saito Y, Suzuki K, Nanba E, Yamamoto T, Ohno K, Murayama S. Niemann-Pick type C disease: accelerated neurofibrillary tangle formation and amyloid beta deposition associated with apolipoprotein E epsilon 4 homozygosity. Ann Neurol. 2002; 52:351-5. [PubMed: 12205649]

Salvioli R, Scarpa S, Ciaffoni F, Tatti M, Ramoni C, Vanier MT, Vaccaro AM. Glucosylceramidase mass and subcellular localization are modulated by cholesterol in Niemann-Pick disease type C. J Biol Chem. 2004; 279:17674-80. [PubMed: 14757764]

Schiffmann R, Dwyer NK, Lubensky IA, Tsokos M, Sutliff VE, Latimer JS, Frei KP, Brady RO, Barton NW, Blanchette-Mackie EJ, Goldin E. Constitutive achlorhydria in mucolipidosis type IV. Proc Natl Acad Sci U S A. 1998; 95:1207-12. [PubMed: 9448310]

Schiffmann R, Mayfield J, Swift C, Nestrasil I. Quantitative neuroimaging in mucolipidosis type IV. Mol Genet Metab. 2014; 111:147-51. [PubMed: 24332805]

Schueler UH, Kolter T, Kaneski CR, Zirzow GC, Sandhoff K, Brady RO. Correlation between enzyme activity and substrate storage in a cell culture model system for Gaucher disease. J Inherit Metab Dis. 2004; 27:649-58. [PubMed: 15669681]

Schulz JB. Mechanisms of neurodegeneration in idiopathic Parkinson's disease. Parkinsonism Relat Disord. 2007; 13(Suppl 3):S306-8. [PubMed: 18267255]

Schulze H, Kolter T, Sandhoff K. Principles of lysosomal membrane degradation: Cellular topology and biochemistry of lysosomal lipid degradation. Biochim Biophys Acta. 2009; 1793:674-83. [PubMed: 19014978]

Shen D, Wang X, Li X, Zhang X, Yao Z, Dibble S, Dong XP, Yu T, Lieberman AP, Showalter HD, Xu H. Lipid storage disorders block lysosomal trafficking by inhibiting a TRP channel and lysosomal calcium release. Nat Commun. 2012; 3:731. [PubMed: 22415822]

Sidransky E, Nalls MA, Aasly JO, Aharon-Peretz J, Annesi G, Barbosa ER, Bar-Shira A, Berg D, Bras J, Brice A, Chen CM, et al. Multicenter analysis of glucocerebrosidase mutations in Parkinson's disease. N Engl J Med. 2009; 361:1651-61. [PubMed: 19846850]

Simon-Sanchez J, Schulte C, Bras JM, Sharma M, Gibbs JR, Berg D, Paisan-Ruiz C, Lichtner P, Scholz SW, Hernandez DG, Kruger R, et al. Genome-wide association study reveals genetic risk underlying Parkinson's disease. Nat Genet. 2009; 41:1308-12. [PubMed: 19915575]

Smith D, Wallom KL, Williams IM, Jeyakumar M, Platt FM. Beneficial effects of anti-inflammatory therapy in a mouse model of Niemann-Pick disease type C1. Neurobiol Dis. 2009; 36:242-51. [PubMed: 19632328]

Smith JA, Chan CC, Goldin E, Schiffmann R. Noninvasive diagnosis and ophthalmic features of mucolipidosis type IV. Ophthalmology. 2002; 109:588-94. [PubMed: 11874766]

Speak AO, Te Vruchte D, Davis LC, Morgan AJ, Smith DA, Yanjanin NM, Simmons L, Hartung R, Runz H, Mengel E, Beck M, et al. Altered distribution and function of natural killer cells in murine and human Niemann-Pick disease type C1. Blood. 2014; 123:51-60. [PubMed: 24235134]

Suzuki K, Parker CC, Pentchev PG, Katz D, Ghetti B, D'Agostino AN, Carstea ED. Neurofibrillary tangles in Niemann-Pick disease type C. Acta Neuropathol. 1995; 89:227-38. [PubMed: 7754743]

Tessitore A, del PMM, Sano R, Ma Y, Mann L, Ingrassia A, Laywell ED, Steindler DA, Hendershot LM, d'Azzo A. GM1-ganglioside-mediated activation of the unfolded protein response causes neuronal death in a neurodegenerative gangliosidosis. Mol Cell. 2004; 15:753-66. [PubMed: 15350219]

Tian X, Gala U, Zhang Y, Shang W, Nagarkar Jaiswal S, di Ronza A, Jaiswal M, Yamamoto S, Sandoval H, Duraine L, Sardiello M, et al. A voltage-gated calcium channel regulates lysosomal fusion with endosomes and autophagosomes and is required for neuronal homeostasis. PLoS biology. 2015; 13:e1002103. [PubMed: 25811491]

Tong Y, Yamaguchi H, Giaime E, Boyle S, Kopan R, Kelleher RJ 3rd, Shen J. Loss of leucine-rich repeat kinase 2 causes impairment of protein degradation pathways, accumulation of alphasynuclein, and apoptotic cell death in aged mice. Proc Natl Acad Sci U S A. 2010; 107:9879-84. [PubMed: 20457918] 
Tseng TT, Gratwick KS, Kollman J, Park D, Nies DH, Goffeau A, Saier MH Jr. The RND permease superfamily: an ancient, ubiquitous and diverse family that includes human disease and development proteins. J Mol Microbiol Biotechnol. 1999; 1:107-25. [PubMed: 10941792]

Thoene, JGE. Pathophysiology of lysosomal transport : 5th International congress on inborn errors of metabolism: Papers. CRC Press; Boca Raton: 1992.

Vanier MT, Millat G. Niemann-Pick disease type C. Clin Genet. 2003; 64:269-81. [PubMed: 12974729]

Visentin S, De Nuccio C, Bernardo A, Pepponi R, Ferrante A, Minghetti L, Popoli P. The stimulation of adenosine A2A receptors ameliorates the pathological phenotype of fibroblasts from NiemannPick type C patients. J Neurosci. 2013; 33:15388-93. [PubMed: 24068806]

Vitner EB, Platt FM, Futerman AH. Common and uncommon pathogenic cascades in lysosomal storage diseases. J Biol Chem. 2010; 285:20423-7. [PubMed: 20430897]

Voeltz GK, Rolls MM, Rapoport TA. Structural organization of the endoplasmic reticulum. EMBO Rep. 2002; 3:944-50. [PubMed: 12370207]

Wang W, Gao Q, Yang M, Zhang X, Yu L, Lawas M, Li X, Bryant-Genevier M, Southall NT, Marugan J, Ferrer M, et al. Up-regulation of lysosomal TRPML1 channels is essential for lysosomal adaptation to nutrient starvation. Proc Natl Acad Sci U S A. 2015; 112:E1373-81. [PubMed: 25733853]

Wang X, Zhang X, Dong XP, Samie M, Li X, Cheng X, Goschka A, Shen D, Zhou Y, Harlow J, Zhu MX, et al. TPC proteins are phosphoinositide- activated sodium-selective ion channels in endosomes and lysosomes. Cell. 2012; 151:372-83. [PubMed: 23063126]

Wang Z, Sun W, Huang CK, Wang L, Xia MM, Cui X, Hu GX, Wang ZS. Inhibitory effects of curcumin on activity of cytochrome P450 2C9 enzyme in human and 2C11 in rat liver microsomes. Drug Dev Ind Pharm. 2015; 41:613-6. [PubMed: 24517573]

Waller-Evans H, Lloyd-Evans E. Regulation of TRPML1 function. Biochem Soc Trans. 2015; 43:4426. [PubMed: 26009188]

Westbroek W, Gustafson AM, Sidransky E. Exploring the link between glucocerebrosidase mutations and parkinsonism. Trends Mol Med. 2011; 17:485-93. [PubMed: 21723784]

Westbroek W, Nguyen M, Siebert M, Lindstrom T, Burnett RA, Aflaki E, Jung O, Tamargo R, Rodriguez-Gil JL, Acosta W, Hendrix A, et al. A new glucocerebrosidase-deficient neuronal cell model provides a tool to probe pathophysiology and therapeutics for Gaucher disease. Dis Model Mech. 2016; 9:769-78. [PubMed: 27482815]

Wilson CA, Murphy DD, Giasson BI, Zhang B, Trojanowski JQ, Lee VM. Degradative organelles containing mislocalized alpha-and beta-synuclein proliferate in presenilin-1 null neurons. J Cell Biol. 2004; 165:335-46. [PubMed: 15123735]

Wong CO, Li R, Montell C, Venkatachalam K. Drosophila TRPML is required for TORC1 activation. Curr Biol. 2012; 22:1616-21. [PubMed: 22863314]

Xu M, Liu K, Swaroop M, Porter FD, Sidhu R, Firnkes S, Ory DS, Marugan JJ, Xiao J, Southall N, Pavan WJ, et al. delta-Tocopherol reduces lipid accumulation in Niemann-Pick type $\mathrm{C} 1$ and Wolman cholesterol storage disorders. J Biol Chem. 2012; 287:39349-60. [PubMed: 23035117]

Yang F, Lim GP, Begum AN, Ubeda OJ, Simmons MR, Ambegaokar SS, Chen PP, Kayed R, Glabe CG, Frautschy SA, Cole GM. Curcumin inhibits formation of amyloid beta oligomers and fibrils, binds plaques, and reduces amyloid in vivo. J Biol Chem. 2005; 280:5892-901. [PubMed: 15590663]

Yamada T, McGeer PL, Baimbridge KG, McGeer EG. Relative sparing in Parkinson's disease of substantia nigra dopamine neurons containing calbindin-D28K. Brain Res. 1990; 526:303-7. [PubMed: 2257487]

Yamaguchi S, Jha A, Li Q, Soyombo AA, Dickinson GD, Churamani D, Brailoiu E, Patel S, Muallem S. Transient receptor potential mucolipin 1 (TRPML1) and two-pore channels are functionally independent organellar ion channels. J Biol Chem. 2011; 286:22934-42. [PubMed: 21540176]

Yu D, Swaroop M, Wang M, Baxa U, Yang R, Yan Y, Coksaygan T, DeTolla L, Marugan JJ, Austin CP, McKew JC, et al. Niemann-Pick Disease Type C: Induced Pluripotent Stem Cell-Derived Neuronal Cells for Modeling Neural Disease and Evaluating Drug Efficacy. J Biomol Screen. 2014; 19:1164-73. [PubMed: 24907126] 
Zhang F, Jin S, Yi F, Li PL. TRP-ML1 functions as a lysosomal NAADP-sensitive Ca2+ release channel in coronary arterial myocytes. J Cell Mol Med. 2009; 13:3174-85. [PubMed: 18754814] 
Extracellular fluid (plasma, interstitial fluid, cerebrospinal fluid) $\mathrm{pH}=\sim 7-7.4, \mathrm{Ca}^{2+}=1.2-1.8 \mathrm{mM}$
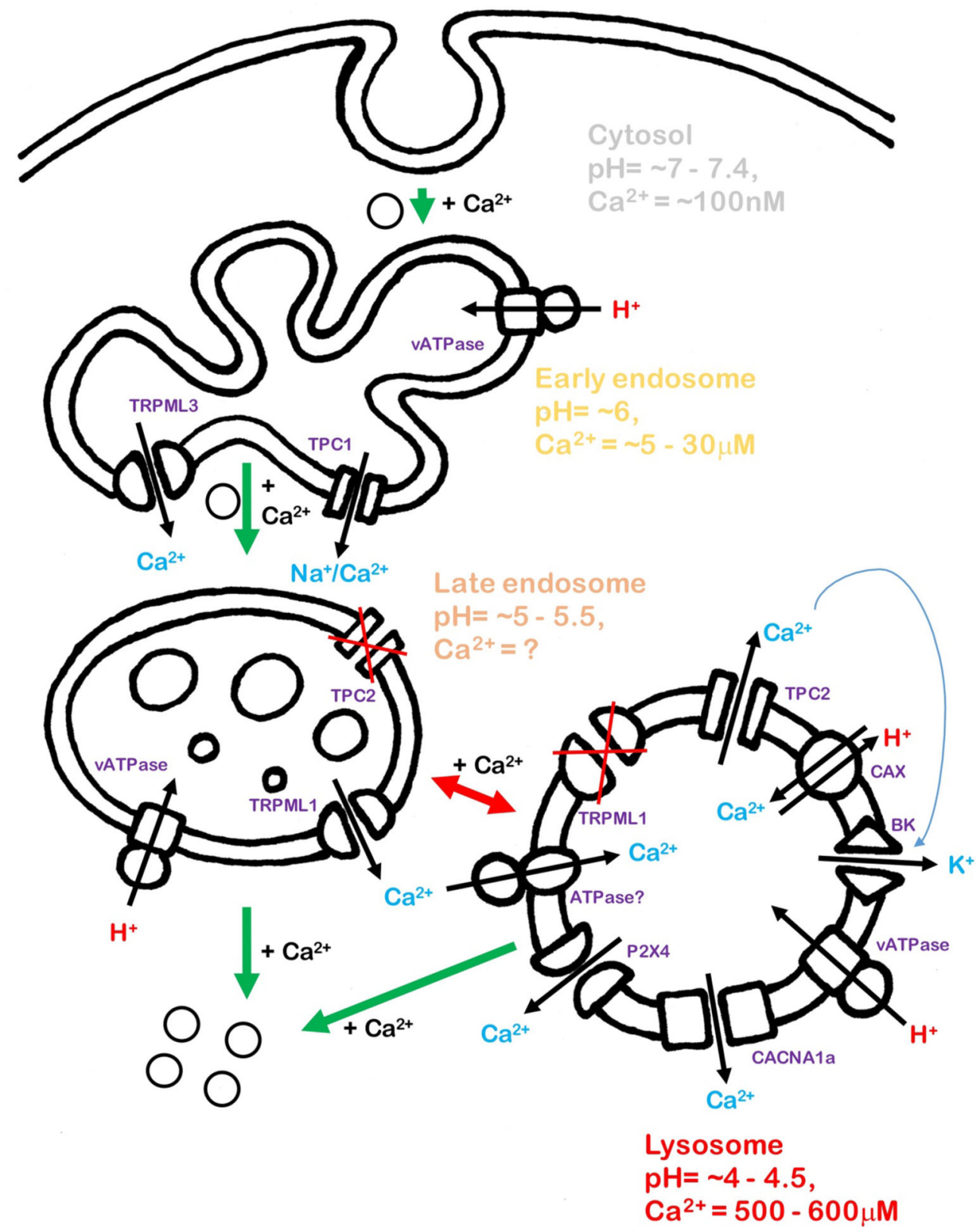

Figure 1. Maturation of the endocytic system is defined by the indicated changes in $\mathrm{pH}$ and $\mathrm{Ca}^{2+}$ concentration as well as the expression of ion channels.

Extracellular $\mathrm{Ca}^{2+}$ levels is high, yet the process of acidification by the vacuolar ATPase (vATPase) results in $\mathrm{Ca}^{2+}$ release out of early endosomes which drives vesicular transport to late endosomes via $\mathrm{Ca}^{2+}$ dependent protein machinery such as Annexin A2. Late endosomes and lysosomes have lower $\mathrm{pH}$ and higher $\mathrm{Ca}^{2+}$ levels which are necessary both for localised events such as vesicular recycling and fusion between late endosomes and lysosomes but also for triggering global changes in $\mathrm{Ca}^{2+}$ via triggering of $\mathrm{ER} \mathrm{Ca}^{2+}$ release. Several new ion channels (indicated and discussed in the text) have been identified on the lysosomal 
membrane in recent years, highlighting the importance of this $\mathrm{Ca}^{2+}$ store to the cell. Green arrows indicate direction of endocytosed cargo (grey circles with black border represent transport vesicles), red arrow indicates fusion between late endosomes and lysosomes, all of these are processes that require local $\mathrm{Ca}^{2+}$ release. 

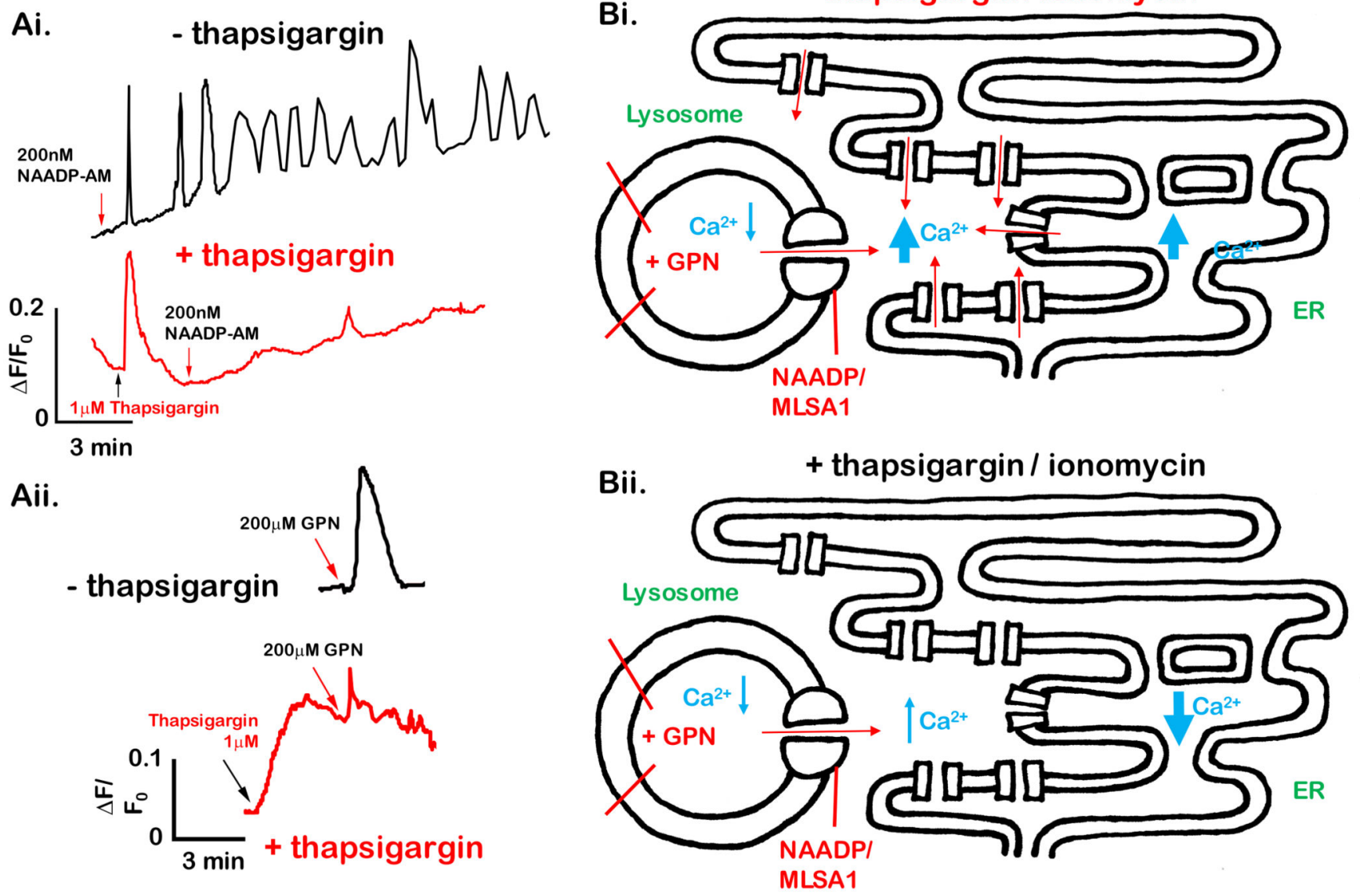

Figure 2. Lysosomes induce $\mathrm{Ca}^{2+}$ release from the ER.

Utilisation of either GPN to burst lysosomes to measure $\mathrm{Ca}^{2+}$ levels or NAADP-AM to release $\mathrm{Ca}^{2+}$ from lysosomes results in a large amount of $\mathrm{Ca}^{2+}$ release (Fig Ai and Aii). This is the result of lysosomal $\mathrm{Ca}^{2+}$ release inducing further $\mathrm{Ca}^{2+}$ release from the ER (Fig. Bi) which can mask real changes in lysosomal $\mathrm{Ca}^{2+}$ levels in cells. In order to properly quantify lysosomal $\mathrm{Ca}^{2+}$ it is necessary to clamp the $\mathrm{Ca}^{2+}$ release from the other stores, this can be done by pretreament of the cells with an inhibitor of $\mathrm{Ca}^{2+}$ mobilisation such as thapsigargin which blocks $\mathrm{Ca}^{2+}$ uptake into the ER via inhibition of SERCA that subsequently uncovers $\mathrm{Ca}^{2+}$ leak out of the ER (Ai and Aii). Following release of the ER store, GPN or NAADP$\mathrm{AM}$ can be added to give a more accurate, smaller, estimate of lysosomal $\mathrm{Ca}^{2+}$, this is summarised in Bii. 


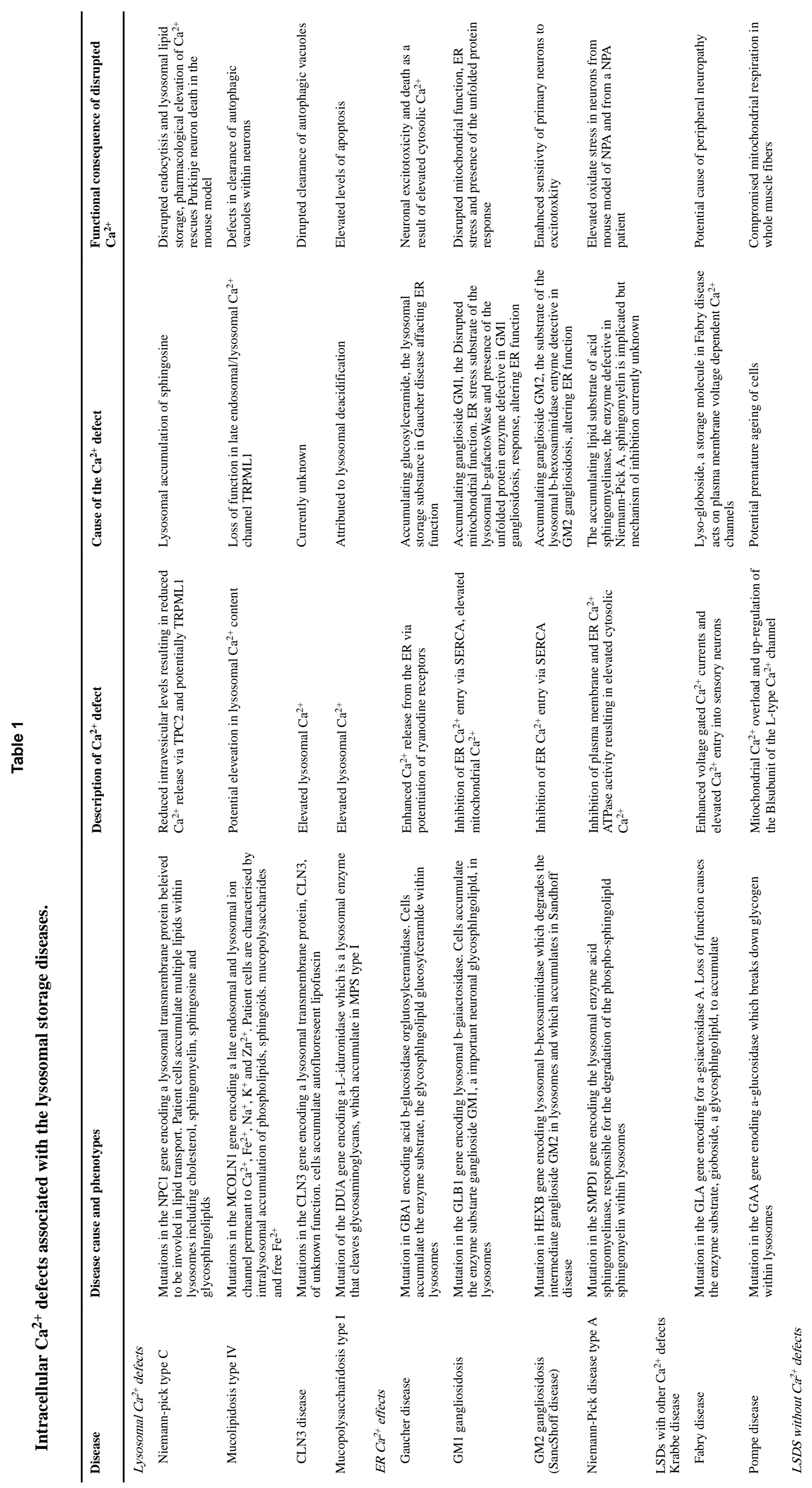




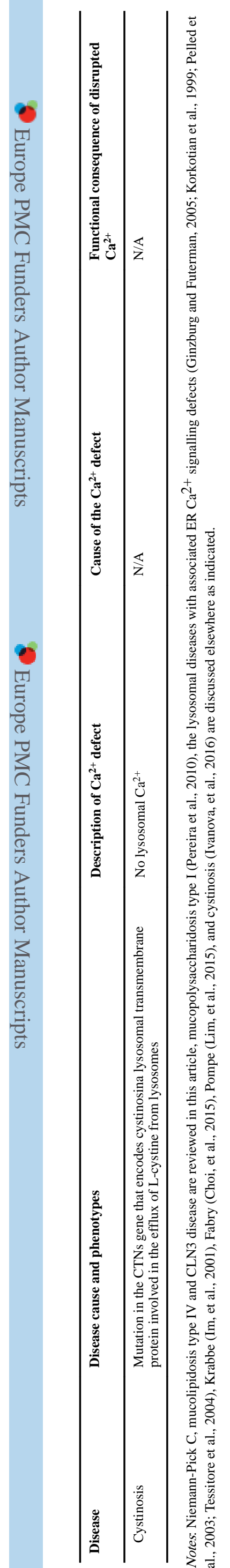


Table 2

Clinical differences and similarities between Niemann-Pick type $\mathbf{C}$ and mucolipidosis type IV patients.

\begin{tabular}{|c|c|c|}
\hline & Mucolipidosis type IV & Niemann-Pick type C \\
\hline \multicolumn{3}{|l|}{ Neurological symptoms } \\
\hline Cerebellar neuron loss & Present late in disease progression & Early event in pathology \\
\hline Thinned corpus callosum & Present & Not Present \\
\hline Developmental delay & Severe & Present \\
\hline Cognitive impairment & Present & Present \\
\hline Epilepsy & Not present & Present \\
\hline Cataplexy & Not present & Present \\
\hline Dystonia & Not present & Present \\
\hline Tremor & Not present & Present \\
\hline Psychiatric disorders & Not present & Present \\
\hline Dementia & Not present & Present \\
\hline Hearing loss & Not present & Present \\
\hline \multicolumn{3}{|l|}{ Opthalmic symptoms } \\
\hline Ocular-motor abnormalities & Not present & Present \\
\hline Corneal clouding & Present & Not present \\
\hline Retinal degeneration & Present & Not present \\
\hline Strabismus & Present & Not present \\
\hline \multicolumn{3}{|l|}{ Visceral symptoms } \\
\hline Hepatospenomegaly & Not present & Present \\
\hline Cholestasis & Not present & Present \\
\hline Dysphagia & Present & Present \\
\hline Dysarthria & Present & Present \\
\hline Achlorydia & Present & Not present \\
\hline Elevated gastrin & Present & Not present \\
\hline Poor physical growth & Present & Not present \\
\hline Hypotonia & Present & Present \\
\hline Lung disease & Not present & Present \\
\hline \multicolumn{3}{|l|}{ Disease progression } \\
\hline Progressive decline & Not present & Present \\
\hline Stability after initial decline & Present & Not present \\
\hline
\end{tabular}

Notes: Overall, only 4/26 phenotypes are shared and these are features that are aligned amongst most neurodegenerative diseases (Altarescu, Sun et al., 2002; Patterson, et al., 2012; Patterson, et al., 2013; Schiffmann et al., 1998; 2014; Smith, et al., 2002). It appears there is little similarity between NPC and MLIV at the patient level, as is the case at the cellular level (Lloyd-Evans and Platt, Cell Calcium 2011). 